\title{
31. MIDDLE EOCENE TO HOLOCENE BENTHIC FORAMINIFER ASSEMBLAGES FROM THE KERGUELEN PLATEAU (SOUTHERN INDIAN OCEAN) ${ }^{1}$
}

\author{
Claudia J. Schröder-Adams²
}

\begin{abstract}
Middle Eocene to Holocene benthic foraminifers were studied in sediments from Sites 736, 738, and 744 (Kerguelen Plateau). Significant faunal changes took place in the middle Eocene, late Eocene/early Oligocene, middle Miocene, and late Miocene. The benthic assemblages are characterized by gradual species replacements. Assemblage boundaries are defined where first appearance datums (FAD's) and last appearance datums (LAD's) concentrate. The Eocene fauna was dominated by Nuttallides truempyi. Buliminids became important at the end of the Eocene and in the early Oligocene Nuttallides umbonifera became dominant. The FAD of $N$. umbonifera is coeval with the onset of the first paleoceanographic indications, such as ice rafted material, of Antarctic glaciation. The establishment of the Antarctic Circumpolar Current in the middle Oligocene is reflected at Site 738 by an erosional hiatus. The increase in relative abundance of Nuttallides umbonifera at Site 744 during the same interval indicates cold, carbonate-corrosive bottom water. Epistominella exigua dominates the bathyal to abyssal upper Miocene to Holocene sediments at Sites 744 and 738, preferring the high supply of organic matter associated with increased upwelling near the Antarctic convergence. Site 736 has a benthic fauna, highly diluted by biosiliceous sedimentation. Significant increases of benthic foraminiferal numbers may indicate changes of the Polar Front during Pliocene/Pleistocene time.
\end{abstract}

\section{INTRODUCTION}

Many deep-water benthic foraminifers are cosmopolitan organisms and their paleontological ranges cover large time spans. Therefore they are not so useful in detailed biostratigraphy as planktonic microfossil groups. Benthic foraminifers are, however, good paleoenvironmental indicators. Marine benthic assemblages are exposed to changing bottom water configurations, as well as to variations in the supply of organic matter due to fluctuations in biological surface productivity. High-latitude areas are of special interest for the study of the impact of paleoenvironmental changes on organisms, because these regions are presently major sources of bottom water masses. In addition, they are characterized by extreme ecological conditions, and they are greatly affected by glacial changes during the Cenozoic.

Ocean Drilling Program (ODP) Leg 119 drilled at six sites along a latitudinal transect across the Kerguelen Plateau, three of which were used in the present study (Fig. 1). This paper concentrates on distinct assemblages and times of faunal change of middle Eocene to Holocene benthic foraminifers. Detailed paleoceanographic discussions based on isotope data are given for the Paleogene and early Miocene by Barrera and Huber (this volume) and for the middle Miocene by Woodruff and Chambers (this volume).

Present surface water masses around Antarctica are influenced by the Antarctic Circumpolar Current (ACC). Sedimentation around Antarctica is altered by the position of the Polar Front which separates biosiliceous sediments in antarctic waters to the south and calcareous sediments in subantarctic waters to the north (Gordon, 1971). Site 736 in middle bathyal depth (629 $\mathrm{m}$ water depth) on the northern part of the plateau is beneath the modern Polar Front. Sites 744 (2307 m water depth) and 738 (2253 m water depth) in upper abyssal depth (for the bathymetric

\footnotetext{
${ }^{1}$ Barron, J., Larsen, B., et al., 1991. Proc. ODP, Sci. Results, 119: College Station, TX (Ocean Drilling Program).

2 Schröder Paleo Consulting, 5828 Dalcastle Crescent N.W., Calgary, Alberta, Canada T3A 1 S4.
}

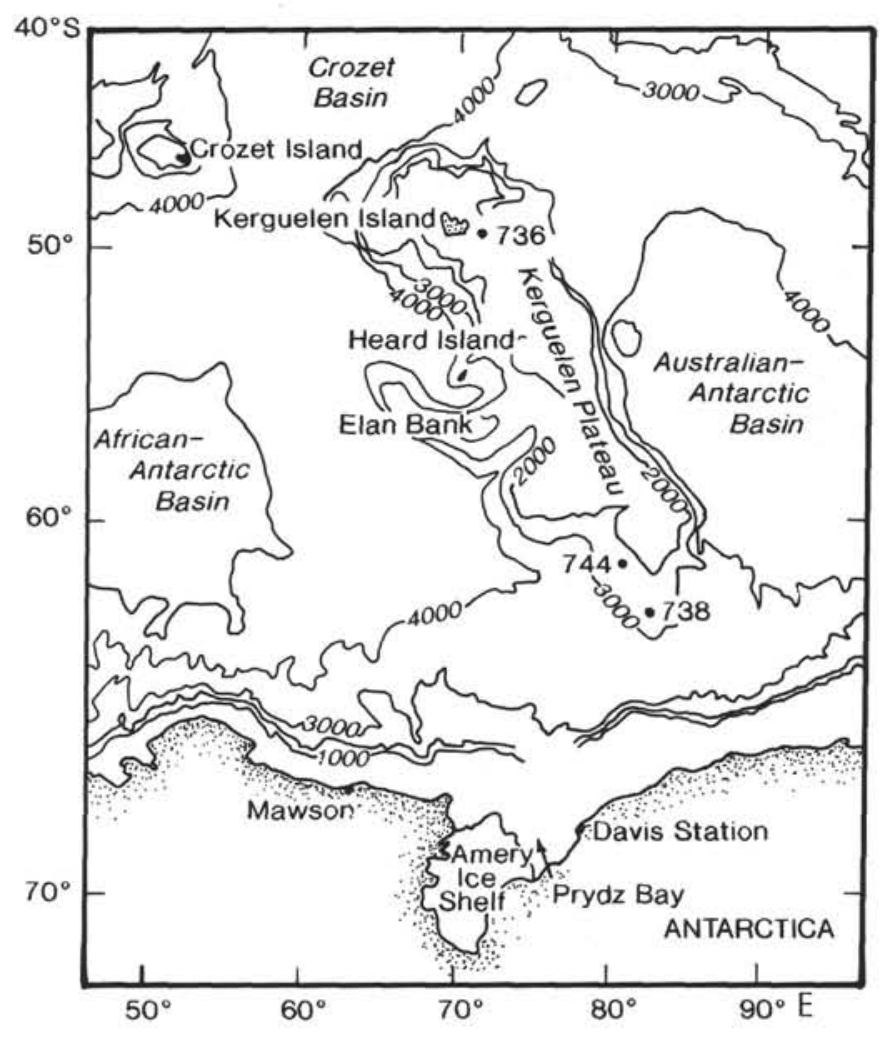

Figure 1. Location map of Sites 736, 738, and 744 on the Kerguelen Plateau. Bathymetry in meters.

division; see Berggren and Miller, 1989) are south of the Polar Front, and are influenced by Circumpolar Deep Water (CPDW) (Lindenberg and Auras, 1984).

Paleogene through Neogene bathyal to abyssal benthic foraminifer assemblages have been studied to a great extent (e.g., Tjalsma, 1983; Tjalsma and Lohmann, 1983; Miller, 1983; Thomas, 1985, 1986a, 1986c; Miller and Katz, 1987). The most 
suitable data of comparison for the assemblage changes discussed here are the results of ODP Leg 120 which are in preparation (A. Mackensen, pers. comm. 1989). Leg 120 drilled the central and southern part of the Kerguelen Plateau and recovered Upper Cretaceous to Holocene sediments (Schlich et al., 1988). Late Cenozoic benthic species of the Ninetyeast Ridge were studied by Boltovskoy (1978). Shallow-water benthic foraminifers from the upper Oligocene to Pleistocene were recorded at Deep Sea Drilling Project (DSDP) Site 270 (Leckie and Webb, 1985). Tertiary benthic foraminifers were described from DSDP Leg 74 on the Walvis Ridge (Boersma, 1984). A continuous benthic foraminiferal record from the Maestrichtian through Neogene of southern high latitudes was recovered during ODP Leg 113 from the Maud Rise in the Weddell Sea (Thomas, 1990). There, large parts of the upper Neogene section are missing as a result of unconformities and calcium carbonate dissolution.

Results of several studies, performed on Quaternary benthic foraminifers and their relationships to bottom water masses in the Indian Ocean (Corliss, 1979a, 1979b; Peterson, 1984), can be used to predict environmental/faunal relationships in the past, presuming that species are responding in a similar manner to ecological parameters through time.

\section{MATERIALS AND METHODS}

Benthic foraminifers from three sites on the Kerguelen Plateau were studied (Fig. 1). Site $736\left(49^{\circ} 24.12^{\prime} \mathrm{S}, 71^{\circ} 39.61^{\prime} \mathrm{E}\right.$; water depth $629 \mathrm{~m}$ ), located on the northern plateau, recovered upper Pliocene to Holocene sediments. Samples $\left(10 \mathrm{~cm}^{3}\right)$ were taken at $1.50 \mathrm{~m}$ intervals. Core recovery averaged $100 \%$ at Hole $736 \mathrm{~B}, 58 \%$ at Hole $736 \mathrm{~A}$, and $20 \%$ at Hole $736 \mathrm{C}$. Site 744 $\left(61^{\circ} 34.65^{\prime} \mathrm{S}, 80^{\circ} 35.46^{\prime} \mathrm{E}\right.$; water depth $\left.2307.8 \mathrm{~m}\right)$ and Site 738 $\left(62^{\circ} 42.54^{\prime} \mathrm{S}, 82^{\circ} 47.24^{\prime} \mathrm{E}\right.$; water depth $\left.2252.5 \mathrm{~m}\right)$ are located on the southern plateau, and recovered upper Eocene to Quaternary (Site 744) and lower Turonian to Quaternary (Site 738) sediments. Samples spaced at $1.50 \mathrm{~m}$ were studied from both sites for the Neogene sections; core-catcher samples only were available from sediments older than Miocene. At Site 738 only Hole $738 \mathrm{~B}$, which reaches into the middle Eocene, was studied; for the late Cretaceous to Paleocene fauna, see Huber (this volume). Hole $738 \mathrm{~B}$ had good core recovery of $79 \%$ with an almost full recovery in the upper $108 \mathrm{~m}$ below seafloor (mbsf). Site 744 reached full recovery in Hole 744B which covers the upper 80 mbsf and in Hole $744 \mathrm{~A}$ for Cores $119-744 \mathrm{~A}-10 \mathrm{H}$ to $119-744 \mathrm{~A}$ $20 \mathrm{H}$.

The biochronology of Barron et al. (this volume), based on the time scale of Berggren et al. (1985), was used to establish a biostratigraphic time frame. The planktonic foraminiferal zonation is obtained from Huber (this volume) and Barron et al. (this volume). The biostratigraphy as derived from all fossil groups revealed a number of unconformities. An unconformity is present in Core 738B-2H, spanning most of the upper Pliocene and lower Pleistocene. Parts of the lower Oligocene through upper Miocene (Section 119-738B-3H-3) are also not represented in sediments. Another unconformity is present at the middle/ upper Eocene boundary at Site 738 . Site 744 was drilled in a comparable water depth in the hope of recovering the missing lower Oligocene to upper Miocene section. The continuous section of fossiliferous sediments recovered at this site complements the record of Site 738 , and both sites offer a base for comparison of benthic foraminifer assemblages. An unconformity in Site 744 of about $5 \mathrm{~m}$.y. duration is present in latest Miocene to Pliocene time (Barron et al., this volume).

Samples were washed through a $0.063 \mathrm{~mm}$ sieve and the residue dried. The entire size fraction $>0.063 \mathrm{~mm}$ was analyzed to ensure the inclusion of the large number of small species (Schröder et al., 1987). In samples with a high abundance of foraminifers a split of approximately 200-300 specimens was identified and counted. In numerous sections, especially at Site 736 , foraminifers are rare. In samples with at least 100 specimens the more abundant species are expressed in relative abundance.

Useful publications for taxonomic species identification were Cushman and Parker (1947), Parker (1964), Boltovskoy (1978), Berggren and Aubert (1976), Thomas (1985, 1986c), Tjalsma and Lohmann (1983), Miller (1983), Miller and Katz (1987), Morkhoven et al. (1986), and Loeblich and Tappan (1987).

\section{RESULTS}

\section{Abundance and Preservation}

Site 736 recovered $370 \mathrm{~m}$ of diatom ooze with a varying input of volcanic debris and a small, nonvolcanic terrestrial, component. The benthic assemblage is characterized by extreme fluctuations in total number of specimens. Barren sections are interrupted by sudden increases to over 8000 individuals per $10 \mathrm{~cm}^{3}$ (Fig. 2). The Quaternary interval generally has a more abundant benthic fauna than the Pliocene interval. All samples below 310 mbsf (Core 119-736C-12R) are barren of foraminifers. The short,

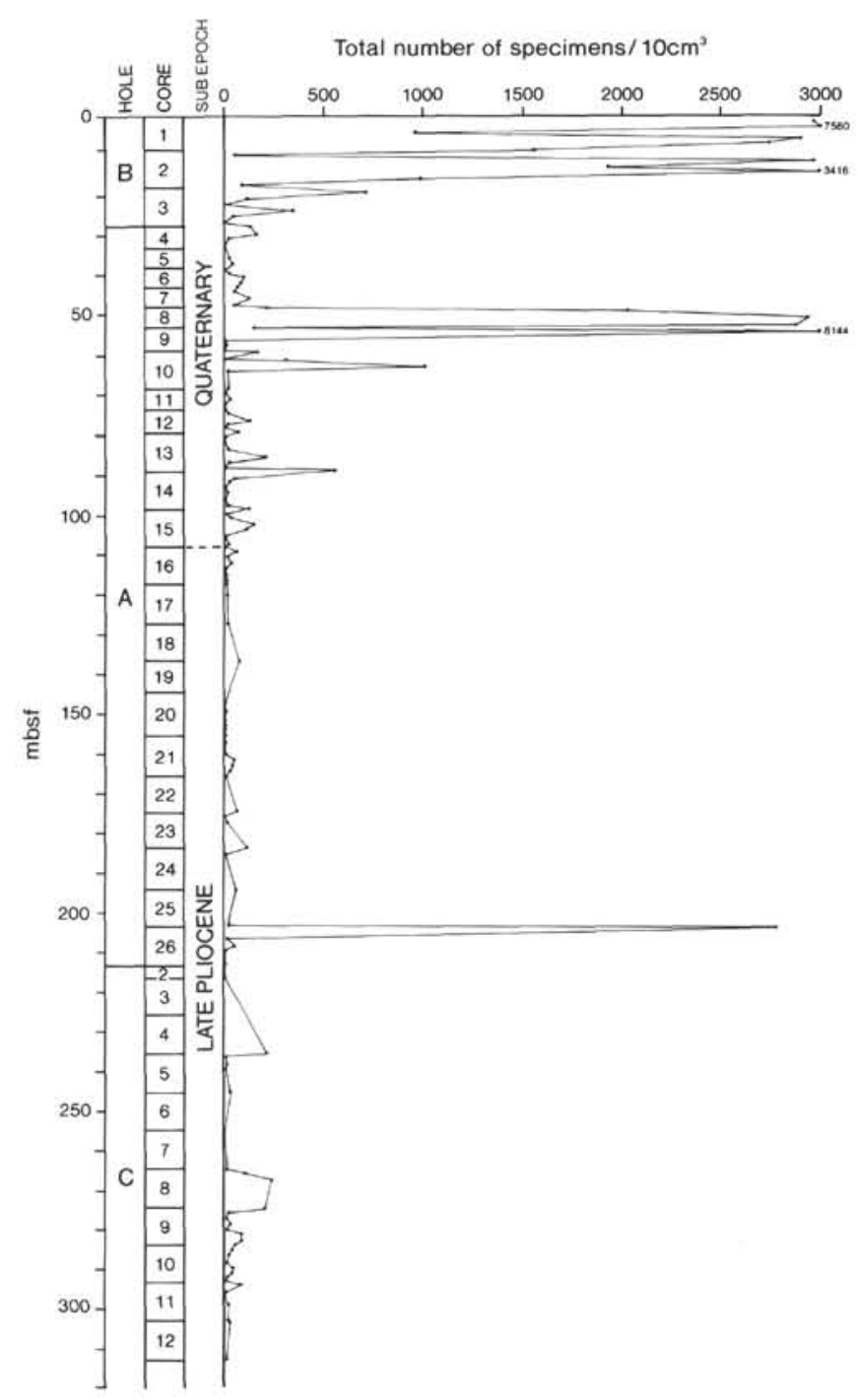

Figure 2. Absolute abundance of benthic foraminifers per $10 \mathrm{~cm}^{3}$ at Site 736. 
dramatic increases of benthic specimens do not show a periodic pattern. Unfortunately the foraminiferal record is too sparse and scattered to attempt to obtain stable isotope data. The presence of planktonic foraminifers varies in a similar manner from the domination of the studied size fraction to a complete absence. All foraminifers are generally well preserved throughout the entire sequence, but show signs of corrosion on SEM photographs.

Characteristic of Site 738 are the Quaternary to upper Pliocene calcareous diatom ooze; a decreased calcareous component during the upper Pliocene to upper Miocene; an abrupt change into nannofossil ooze down to the middle Eocene, and the presence of calcareous chalk and limestone below the middle Eocene. Benthic foraminifers are rare compared to the number of planktonic foraminifers, but the numbers are in most sections sufficient for a quantitative study. The interval above an unconformity separating the upper Miocene from the lower Oligocene (Samples 119-738B-2H-6; 115-120 cm, to 119-738B-3H-2; 80$85 \mathrm{~cm}$ ) is barren of calcareous species, but contains rare agglutinated specimens. These samples have an increased terrigenous mineral component and contain abundant diatoms and radiolarian tests in the $>0.063 \mathrm{~mm}$ size fraction. Agglutinated tests and pebble-sized particles have ferromanganese coatings, indicating a high oxygen content of the waters and a slow sedimentation rate. This suggests the presence of an erosional surface. The preservation of benthic foraminifers throughout the Eocene to Neogene sediments is generally good, but specimens show some signs of corrosion such as a rough surface of the test and broken chambers.

Site 744 contains highly fossiliferous sediments, consisting of a calcareous diatom ooze in the Pliocene/Pleistocene sequence, and nannofossil ooze from the Eocene to Miocene. Benthic foraminifers are present in varying numbers, but generally common throughout the entire sequence. Specimens are well preserved. In the middle part of the Pliocene (Sample 119-744B-2H-5, 25-27 $\mathrm{cm} ; 15.75 \mathrm{mbsf}$ ) numbers of planktonic and benthic foraminifers decrease drastically for a short interval. The residue is dominated by mineral grains, large-sized diatom and radiolarian tests, and rare agglutinated foraminiferal specimens. The lithological sequences at Sites 744 and 738 are similar phenomena within an equivalent age sequence.

\section{Foraminiferal Changes}

The entire benthic foraminiferal assemblage of the studied material contains a total of more than 200 species. Benthic assemblages are commonly dominated by a small number of taxa, and the fluctuations in relative abundances in this continuous record indicate paleoenvironmental changes. Precise biostratigraphic ranges for a large number of rare species cannot be determined. In addition, the confusing taxonomy of benthic foraminifers and the different size fractions used do not facilitate a comparison between different studies (Boltovskoy, 1978, 1980; Thomas, 1990). At this point the identification of numerous species is still in progress, and this study concentrates on the more common species.

Five benthic assemblages are recognized in the middle Eocene to Quaternary sequence of Sites 738 and 744. Their boundaries are marked through FAD's and LAD's in a defined interval. These faunal changes are assigned to one particular sample by choosing the LAD's of certain species. The assemblage boundaries, however, are marked in some cases by a transitional zone, where a gradual change in species composition takes place. The middle bathyal Pliocene/Pleistocene assemblage represented in Site 736 differs from these five assemblages and is discussed separately.

\section{Site 738}

Sites 738 and 744 have to be discussed in close association because Site 744 includes the interval that was not deposited at Site 738 due to a hiatus. The following five assemblages and their ages derived from the correlation with planktonic microfossil groups (Barron, et al., this volume) are recognized:

Assemblage 1: latest Miocene to Quaternary

Assemblage 2: late middle Miocene to early late Miocene

Assemblage 3: early Oligocene to middle Miocene

Assemblage 4: latest middle Eocene to late Eocene

Assemblage 5: early middle Eocene to late middle Eocene

Drilling at Site 738 recovered lower Turonian to Pleistocene sediments, however, only middle Eocene to Quaternary benthic foraminifers are described here. Assemblages 1 and 3-5 are present whereas Assemblage 2 is missing because of an unconformity. Many FAD's and LAD's are questionable because of the unconformities. Therefore, a positioning of the upper boundary of Assemblage 3 and the lower boundary of Assemblage 1 is not precise. Changes of selected dominant species are illustrated in Figure 3 and biostratigraphic ranges of species are shown in Figure 4. Appendix $\mathrm{A}$ is an alphabetical list of those species in Figure 4; Appendix B is a list of all identified species.

\section{Assemblage 5: early middle Eocene to late middle Eocene}

The lower boundary of Assemblage 5 cannot be defined because no samples were studied below Sample 119-738B-24X-CC (214.3 mbsf). The upper boundary of this assemblage is chosen at the LAD of Alabamina dissonata, Anomalina spissiformis, Bolivina huneri, and Bulimina basistriata var. nuda in Sample 119-738B-10H-CC ( 85 mbsf). Several other species have a LAD within this interval. The FAD's of these species do not occur within the studied sequence and their exact ranges have to remain uncertain. The assemblage is dominated by Nuttallides truempyi, Bulimina thanetensis, Bulimina simplex, Stilostomella spp., and Orthomorphina antillea.

\section{Assemblage 4: latest middle Eocene to late Eocene}

Assemblage 4 ranges from Sample 119-738B-9H-CC ( $80 \mathrm{mbsf}$ ) to Sample 119-738B-5H-CC (42 mbsf). The upper boundary of Assemblage 4 is represented by a transitional zone, which includes several LAD's of important species. The relatively large intervals between samples (only core-catcher samples were used) possibly prohibit an exact positioning of the boundary. The last occurrence of $N$. truempyi appears in the uppermost Eocene (Sample 119-738B-6H-CC; 51.50 mbsf). Orthomorphina havanensis has its LAD slightly higher. Bulimina semicostata shows a short range within the upper Eocene. Nonion havanensis and Neoeponides lunata disappear at the Eocene/Oligocene boundary. Some LAD's cannot be determined because of a suggested hiatus at the middle/upper Eocene boundary. The range of $B$. simplex, a species ranging into the Oligocene at Site 744 , Bulimina elongata, and Stilostomella gracillima may be affected by a lower Oligocene hiatus. No major extinction event occurs at the Eocene/Oligocene boundary, but rather a more gradual faunal change takes place.

\section{Assemblage 3: early Oligocene}

Assemblage 3 is only represented by two samples in the lower Oligocene (Sample 119-738B-4H-CC; 32.50 mbsf and 119-738B$3 \mathrm{H}-\mathrm{CC} ; 23 \mathrm{mbsf}$ ). The upper part is missing because of a large hiatus in this interval. Most of the representative species of the Oligocene sequence, which were identified at Site 744, are miss- 


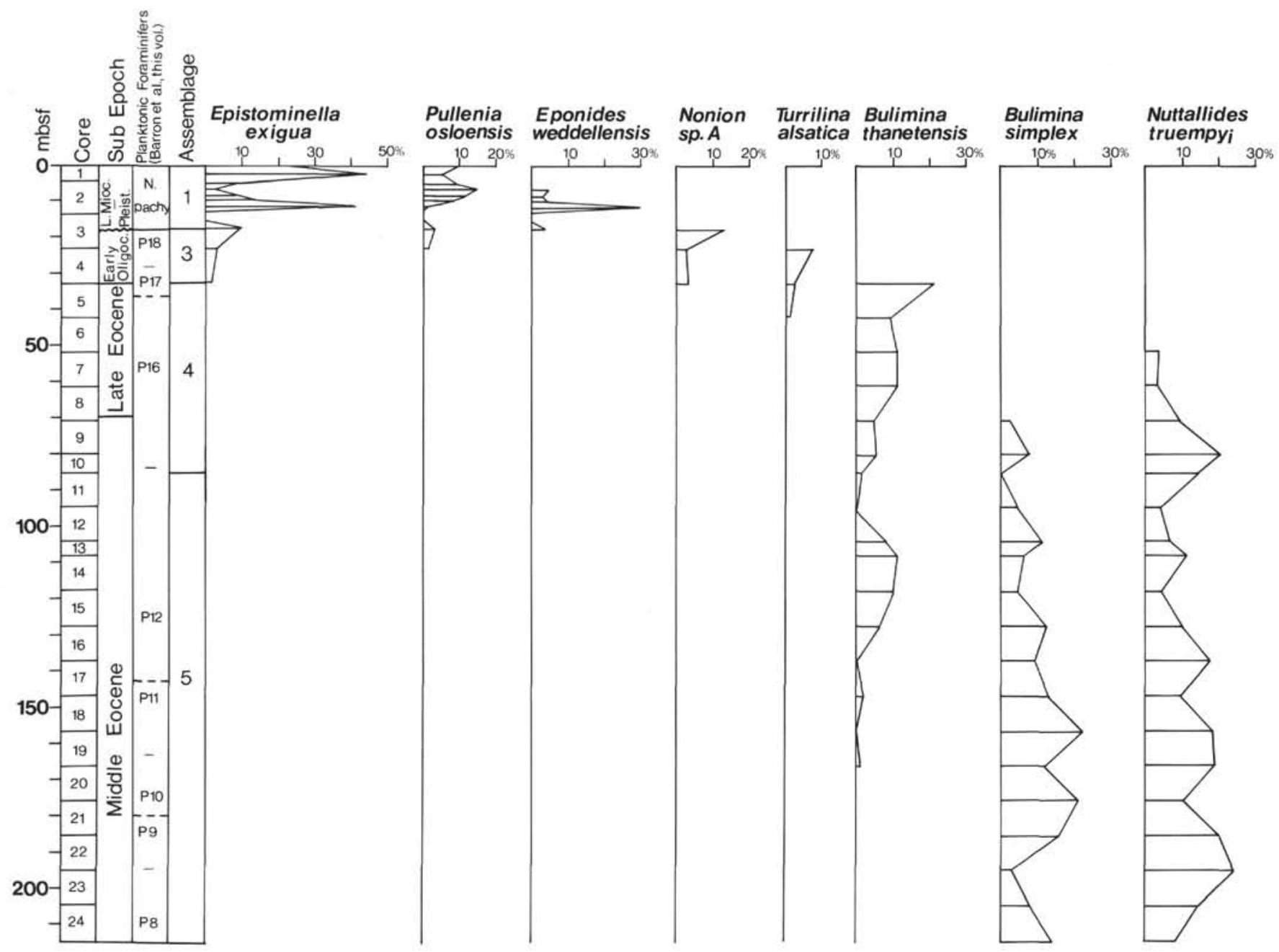

Figure 3. Relative abundance of selected species at Site 738, including all studied samples of Hole 738B.

ing. Common species such as Nuttallides umbonifera, Laticarinina pauperata, and Gyroidina spp. occur rarely. The interval is characterized by the short range of Turrilina alsatica and Nonion sp. A. A large group of taxa disappears at the hiatus and therefore has unknown LAD's at Site 738. These species are $B u$ limina thanetensis, Orthomorphina antillea, Bolivinopsis cubensis, Stilostomella subspinosa, Cibicidoides ungerianus, and Astrononion umbilicatulum.

Assemblage 1: late Miocene to Pleistocene

Assemblage 1 ranges from Sample 119-738B-3H-3, 90-94 cm (17.40 mbsf), to the mud-line sample, spanning the upper Miocene to Holocene. Dominant species are Epistominella exigua, Epistominella vitrea and Pullenia osloensis. Eponides weddellensis is common in the upper Miocene. The FAD's of most species in this assemblage cannot be determined due to the hiatus at the lower boundary.

\section{Site 744}

Drilling at Site 744 recovered upper Eocene to Holocene sediments and the benthic foraminiferal fauna is represented by Assemblage 4 to Assemblage 1. Figure 5 shows the relative abundances of abundant species that dominate the distinct benthic assemblages. Biostratigraphic ranges of selected species are shown in Figure 6 (Appendix A is an alphabetical list of those species in Fig. 6).

\section{Assemblage 4: late Eocene}

The lower boundary of Assemblage 4 cannot be defined at this site; only three samples were studied within the upper Eocene. The upper boundary of this assemblage is drawn in Sample 119-744A-18H-CC (157.1 mbsf) just below the Eocene/Oligocene boundary. This boundary, comparable to Site 738 , is not marked by an abrupt turnover of species but rather by a gradual change in species composition. Nuttallides truempyi, an important Eocene marker (Tjalsma and Lohmann, 1983), has its LAD in Sample 119-744A-20H-CC. Other LAD's below the Eocene/Oligocene boundary are of Stilostomella gracillima and Osangularia mexicana. Species that have their LAD just below the boundary are Hanzaweia ammophila, Gyroidinoides globosus, and Gavelinella semicribrata. Dominant species are Bulimina simplex (Fig. 4), Stilostomella spp., Cibicidoides ungerianus, and Orthomorphina antillea.

\section{Assemblage 3: Early Oligocene to late middle Miocene}

Assemblage 3 ranges from Sample 119-744A-17H-CC (147.6 mbsf) to Sample 119-744B-7H-5, 120-125 cm (57.20 mbsf). The lower Oligocene is marked by the short range and relatively high abundance of Turrilina alsatica (Fig. 5). The upper boundary is placed at the LAD of Bolivinopsis cubensis in the upper middle Miocene (Sample 119-744B-7H-5, 120-125 cm). Nuttallides umbonifera, Astrononion umbilicatulum, and Epistominella ex- 
igua, three important species in the upper Paleogene and Neogene, have their FAD's within the Oligocene. N. umbonifera dominates throughout the assemblage. Stilostomella spp. and Bigeneria nodulosa are common, but their ranges extend beyond the discussed sequence.

\section{Assemblage 2: late middle to early late Miocene}

Assemblage 2 includes Sample 119-744B-7H-4, 120-125 cm (55.70 mbsf), to Sample 119-744B-4H-7, 25-27 cm (30.75 mbsf), and is defined by a number of short-ranging taxa which are relatively abundant and have their FAD's and LAD's within the upper middle Miocene to the uppermost Miocene interval. This group includes Sigmoilina edwardsi, Eponides sp. A, Quinqueloculina venusta, Spiroloculina depressa, Ophthalmidium pusillum, and Uvigerina proposcidea. Important LAD's of longer ranging taxa in this zone are of $B$. nodulosa (Sample 119-744B$5 \mathrm{H}-1,125-130 \mathrm{~cm} ; 32.25 \mathrm{mbsf}$ ) and $N$. umbonifera (Sample $119-744 \mathrm{~B}-5 \mathrm{H}-3,125-130 \mathrm{~cm} ; 35.25 \mathrm{mbsf}$ ). The assemblage is dominated by Bolivina thalmanni (Fig. 5) which has its FAD in the upper lower Miocene (Sample 119-744B-9H-4, 125-130 cm; $74.75 \mathrm{mbsf}$ ).

\section{Assemblage 1: latest Miocene to Quaternary}

Assemblage 1 ranges from Sample 119-744B-4H-6, 25-27 cm ( $29.25 \mathrm{mbsf}$ ) to the mud-line sample and is dominated by $E$. exigua and Epistominella vitrea. Both taxa reach their highest relative abundance in the Quaternary (Fig. 5). Several consistently present species with long ranges have their LAD's in the uppermost Pliocene to lower Pleistocene: Laticarinina pauperata, Uvigerina peregrina, Pleurostomella obtusa, Bolivina thalmanni and others (Fig. 6). Typical Quaternary species are Nonionella iridea and Triloculina oblonga.

\section{Comparison of Site 744 and 738}

Combination of the sections cored at Sites 738 and Site 744 includes a complete benthic record from the middle Eocene to the Quaternary. The sites are at a similar water depth and approximately $250 \mathrm{~km}$ apart. A correlation of assemblage boundaries is illustrated in Figure 7. Assemblage 1, ranging from the uppermost Miocene to Holocene, is represented at both sites, although in a more compressed interval at Site 738 due to hiatuses. A short barren zone in this interval, indicating an erosional surface, is present at both sites. Epistominella exigua, E. vitrea, and Pullenia osloensis dominate both assemblages. The increase in abundance of Eponides weddellensis in the upper Miocene occurs at both sites, but it is more pronounced at Site 738.

At Site 744, Assemblage 2, ranging through late middle Miocene to early late Miocene time, is well developed and has a large number of species. This assemblage is missing at Site 738, due to a hiatus. Bolivina thalmanni, abundant at Site 744 , is absent at Site 738. Nuttallides umbonifera is abundant at Site 744, but is reduced at Site 738 to two rare occurrences in the lower Miocene and lower Oligocene.

Assemblage 3 characterizes the lower Oligocene to middle Miocene sequence. Only the lowermost Oligocene is present at both sites, whereas the upper Oligocene to middle Miocene interval occurs only at Site 744. The lower Oligocene is marked at both locations by the short range of Turrilina alsatica complemented by Nonion sp. A. The occurrence of T. alsatica compares with high numbers of this taxon at Site 689, where it has its FAD in the late Eocene (Thomas, 1990). The late Oligocene/ early Miocene relative abundance increase of Bulimina simplex together with common occurrences of Astrononion umbilicatulum and Nuttallides umbonifera, is lacking at Site 738 because of the hiatus.
Assemblage 4 is well developed at Site 738, but is represented only in the lowermost two samples of Site 744. The uppermost Eocene is dominated by buliminids. Site 744 has high numbers of $B$. simplex and Site 738 has high numbers of Bulimina thanetensis. Assemblage 5 is only documented at Site 738 and is dominated by Nuttallides truempyi.

A comparison of the ranges of individual species between Sites 744 and 738 is problematical due to the impossibility of establishing the LAD's of many species in the upper Oligocene to middle Miocene interval, where an unconformity is present at Site 738. Certain differences in LAD's of species occur at the Eocene/Oligocene boundary, but the rarity of these species and the large sample intervals make a comparison doubtful.

During the studied interval, Sites 738 and 744 represent a middle bathyal to abyssal depositional environment with a deepening trend from the Eocene to Neogene. The high relative abundance of $N$. truempyi suggests for the Eocene a lower to middle bathyal paleo water depth (Morkhoven et al., 1986). The Oligocene fauna with high numbers of $N$. umbonifera, E. exigua, and Cibicidoides mundulus imply a lower bathyal paleoenvironment of $1000-2000 \mathrm{~m}$. The Neogene section is placed into the upper abyssal bathymetric range (2000-3000 m) with typical modern deep-water species such as E. exigua, Oridorsalis umbonatus, and Cibicidoides wuellerstorfi.

\section{Site 736}

Site 736 was drilled in middle bathyal water depth. The foraminifer assemblage is less diverse and differs in species composition in comparison with the same time interval at Sites 738 and 744 at an upper abyssal depth. Over the short time interval recovered, no significant assemblage changes occurred. Changes of the most common species are expressed in relative abundance (Fig. 8). Most dominant species occur over the entire sequence, although with extreme changes in absolute abundance. The uppermost 20 mbsf are dominated by Bulimina aculeata, Nonionella iridea, and Fursenkoina spp. Less common species are Stainforthia complanata and Bolivina pseudopunctata. Below 20 mbsf Cassidulina oblonga, Angulogerina earlandi, and Sphaeroidina bulloides are abundant. Pullenia bulloides and Eponides pusillus are common. These species occur sporadically throughout the Pliocene with high peaks in single samples followed by barren intervals. Below 300 mbsf all samples were barren of benthic foraminifers. The species composition suggests a middle bathyal paleo water depth throughout the late Pliocene to Holocene similar to the present water depth of Site 736.

A similar foraminiferal assemblage was observed by Mackensen et al. (in press), who studied living and dead Holocene faunas in the Eastern Weddell Sea, where Trifarina angulosa (Angulogerina earlandi in this study) is correlated with coarse sediment at a water depth of $1500 \mathrm{~m}$, where the biotope is well oxygenated and noncorrosive to calcium carbonate because of bottom currents. These conditions preserve this species in the dead assemblage and provide a high potential for fossilization (Mackensen et al., in press). At Site 736 this species occurs sporadically, but then in high numbers throughout the Pliocene/ Pleistocene. $N$. iridea and $B$. aculeata are considered infaunal species and are associated in the Weddell Sea with a high supply of organic matter in a fine substrate. In the dead assemblage a few centimeters below the surface, the tests are dissolved because of the high organic carbon content (Mackensen et al., in press). Both species occur at Site 736 in the upper 10 mbsf. $N$. iridea disappears below this interval whereas $B$. aculeata shows another high abundance (up to $50 \%$ ) at 285 mbsf.

Another study for comparison was performed on surface samples along a transect west of Heard Island (Lindenberg and 
A

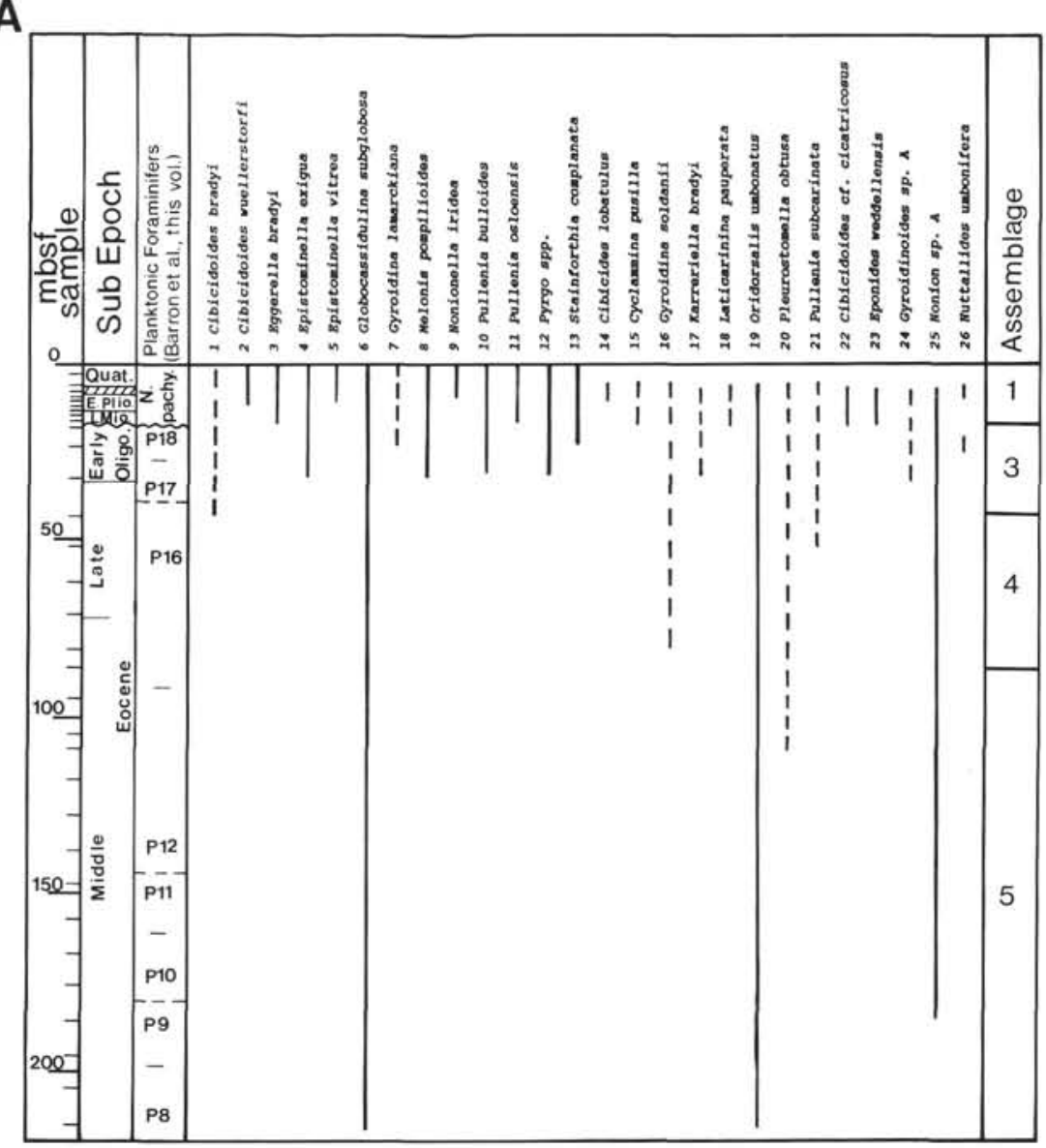

Figure 4. Vertical ranges of selected benthic species at Hole 738B. Species are arranged according to their last appearance. A solid line represents a continuous, frequent, common, or abundant occurrence ( $>2 \%$ relative abundance); a broken line represents an irregular, rare occurrence ( $<2 \%$ relative abundance). For an alphabetical species list, see Appendix A.

Auras, 1984). B. aculeata and A. earlandi were dominant at a middle bathyal water depth.

\section{DISCUSSION}

Benthic foraminifer assemblages from the Pliocene/Pleistocene section on the northern Kerguelen Plateau and from the same interval on the southern plateau indicate two different environments. Site 736 is located beneath the present Antarctic Convergence, a major water-mass boundary, associated with increased rates of upwelling and, consequently, a high production of planktonic biomass. This is reflected in the rapid sedimentation rate of biosiliceous tests, reaching a minimum of $140 \mathrm{~m} /$ m.y. during the Pliocene and $54 \mathrm{~m} / \mathrm{m}$.y. during the Quaternary (Barron, Larsen, et al., 1989). The high production of siliceous organisms means an increased nutrient supply in the form of organic matter for benthic foraminifers. On the other hand, high siliceous sedimentation rates dilute the foraminiferal component, which is reflected by the numerous barren intervals, especially in the Pliocene. Dissolution of calcium carbonate because of the high supply of organic matter could also be a factor influencing the foraminiferal assemblage. This cause is suggested for large barren intervals during the middle Miocene to Pleistocene of the Maud Rise (Thomas, 1990). The present calcareous foraminiferal tests of numerous delicate species at Site 736 do not show signs of corrosion. Present-day oceanographic conditions in this region were established in the latest Miocene to early Pliocene (Kemp et al., 1975; Barron, Larsen, et al., 1989). Small shifts of the Polar Front in the past caused detectable changes in the composition of the sediment. The observed short pulses of increased numbers of foraminifers at Site 736 may be an indication of either the stronger influence of subantarctic waters or the decreased surface productivity and consequently decreased dilution of the calcareous component or increased preservation of foraminiferal tests. It has been suggested that a low diversity Neogene assemblage dominated by Bulimina aculeata may represent oceanographic conditions with a high supply of organic matter (Mackensen et al., in press). This situation compares with that at Site 736 , where B. aculeata dominates the upper $10 \mathrm{~m}$ of sediment.

The recovered sediments of the southern Kerguelen Plateau (Sites 738 and 744) document several changes within the benthic foraminiferal assemblage during Eocene to Quaternary time. The Eocene fauna was dominated by Nuttallides truempyi, which had a worldwide distribution in lower Cretaceous to Eocene deep-water sediments (Tjalsma and Lohmann, 1983; Miller et al., 1984). This species was replaced in the late Eocene by several Bulimina species. Above the Eocene/Oligocene boundary Nuttallides umbonifera appeared and increased in relative abundance in the middle early Oligocene. Other long-ranging taxa with a broad bathymetric distribution, such as Oridorsalis umbonatus, Globocassidulina subglobosa, Gyroidina spp., and Pullenia bulloides, complement this assemblage. A similar fau- 
B

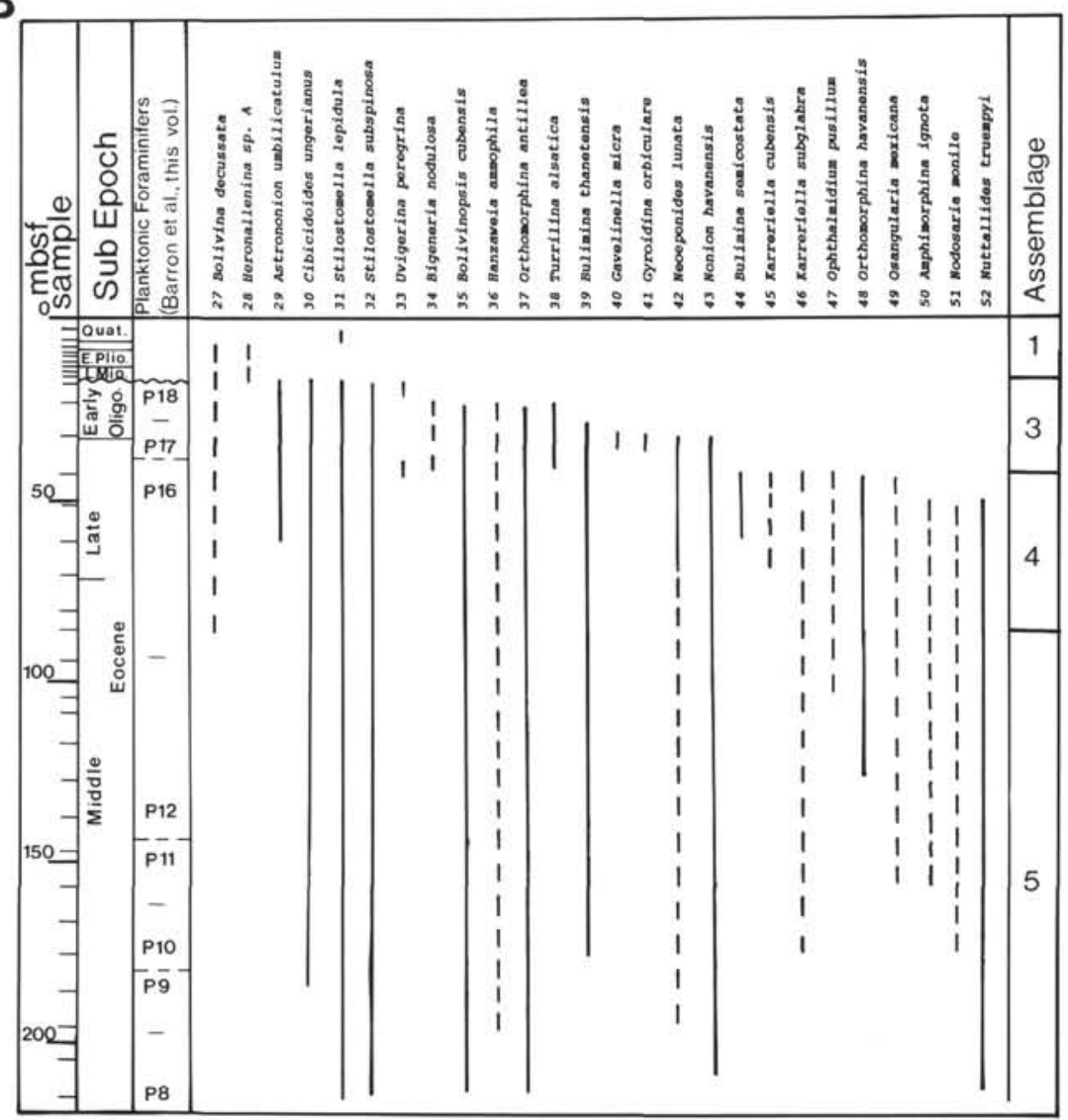

C

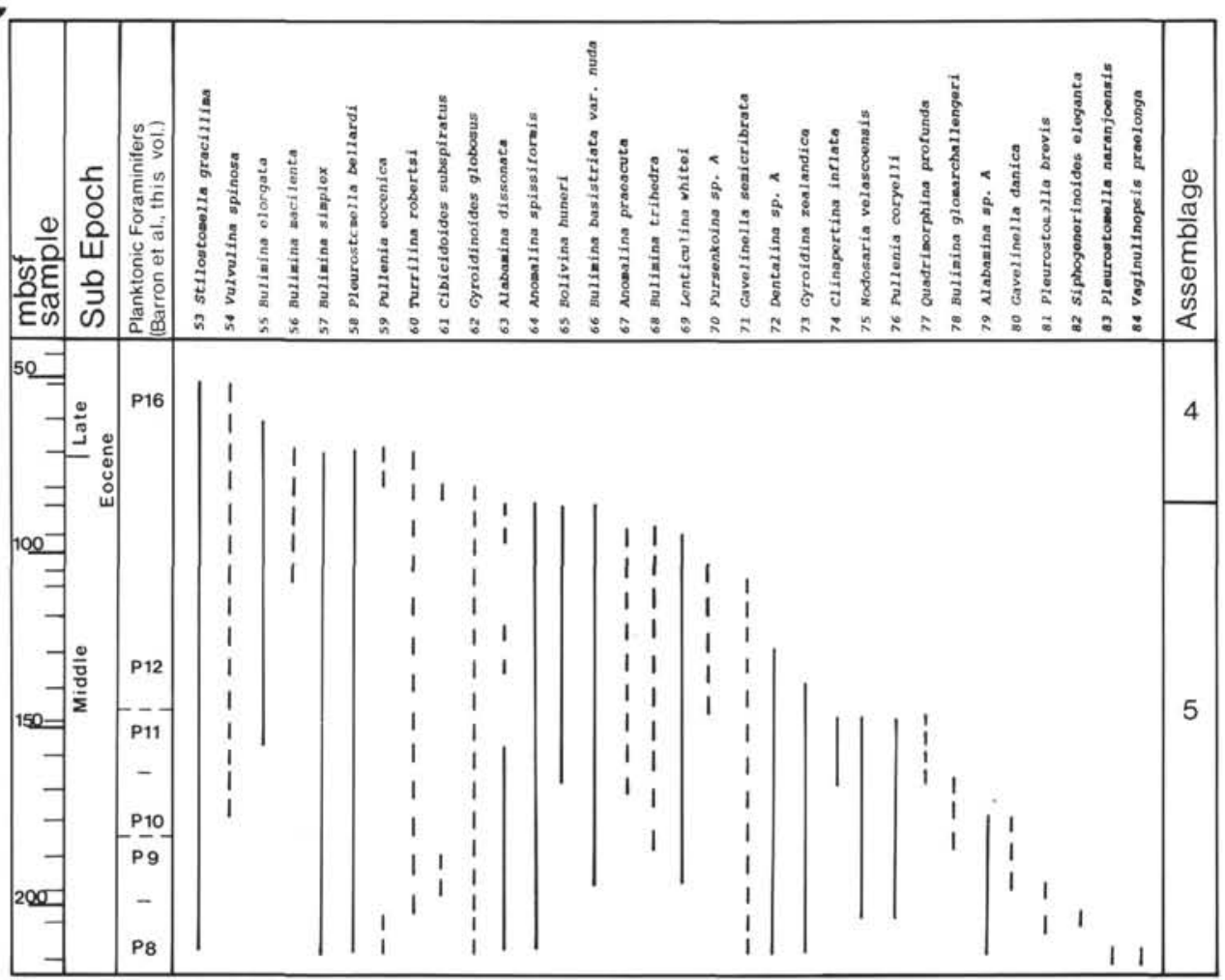

Figure 4 (continued). 


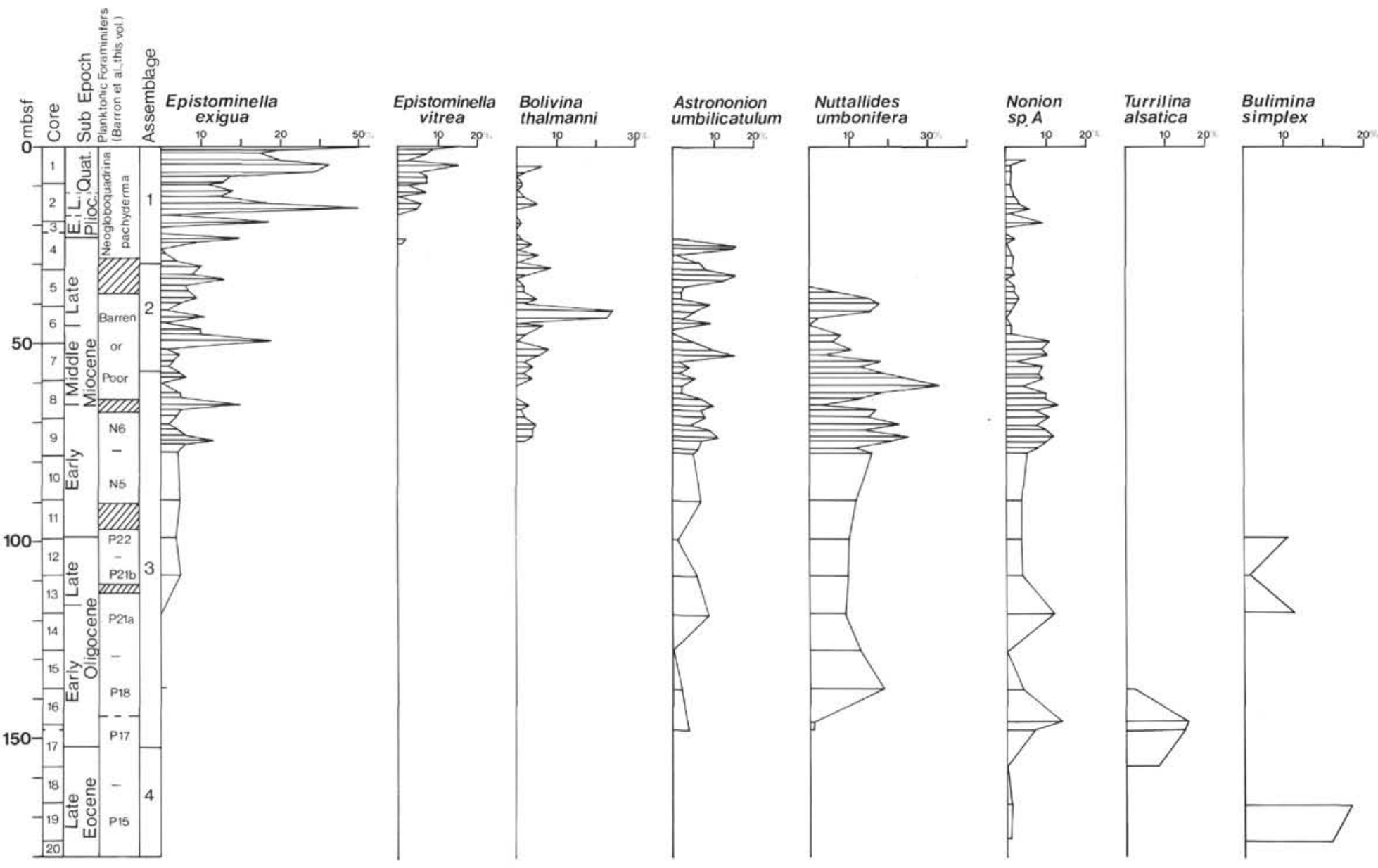

Figure 5. Relative abundance of selected species at Site 744, including all studied samples from Hole 744B (Cores $1 \mathrm{H}-9 \mathrm{H})$ and from $\mathrm{Hole} 744 \mathrm{~A}(\mathrm{Cores} 10 \mathrm{H}-20 \mathrm{H})$. 

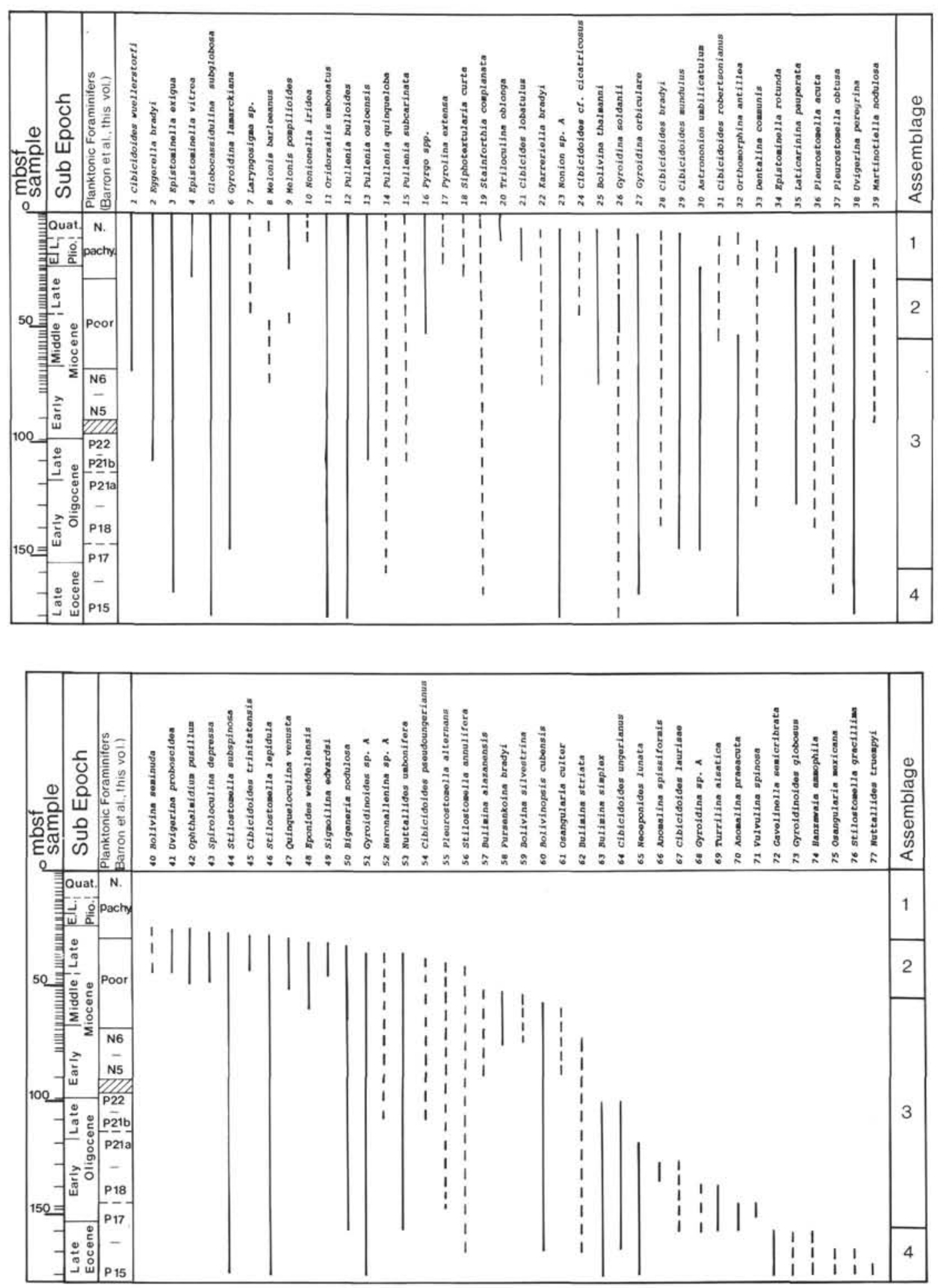

Figure 6. Vertical ranges of selected benthic species at Site 744. Species are arranged according to their last appearance. A solid line represents a continuous, frequent, common, or abundant ( $>2 \%$ relative abundance); a broken line represents an irregular, rare occurrence $(<2 \%$ relative abundance). For an alphabetical species list, see Appen$\operatorname{dix}$ A.

nal change at the end of the Eocene was described from the Bay of Biscay and explained by a bottom water change from old, warm, and carbonate corrosive to younger, colder and more vigorously circulating bottom water of Arctic origin (Miller et al., 1984).
The described faunal change at the Eocene/Oligocene boundary is a gradual one without a distinct diversity change. The upper Eocene has a larger number of LAD's whereas the lower Oligocene is marked by more FAD's. This trend has also been described from many other studied localities (Tjalsma and Loh- 


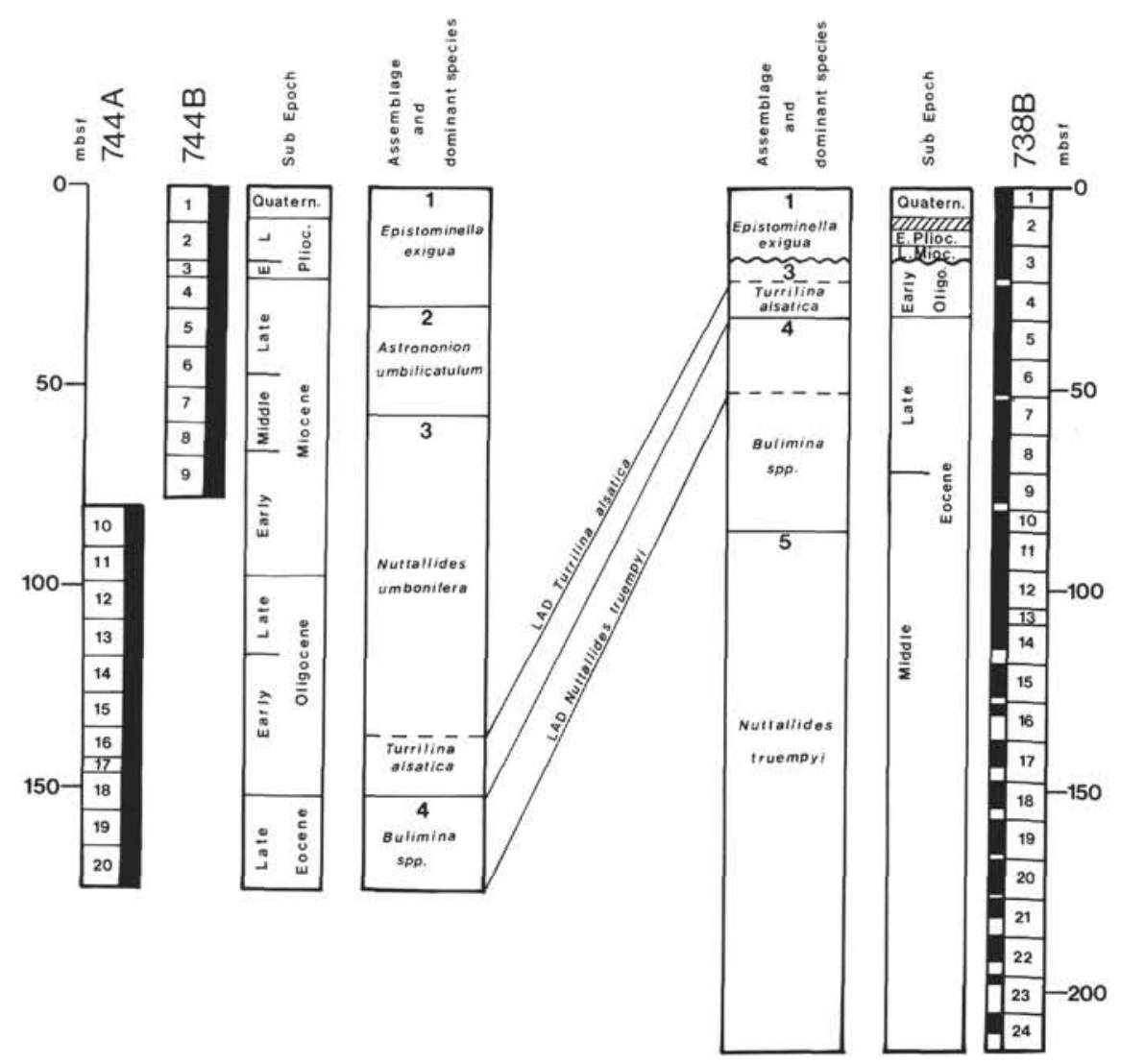

Figure 7. Comparison of benthic foraminiferal assemblages and their dominant species recovered at Sites 738 and 744. The boundary between Assemblage 3 and 4, and the LAD of Turrilina alsatica and Nuttallides truempyi are correlated.

mann, 1983; Miller et al., 1984; Corliss, 1981; Corliss et al., 1984; Thomas, 1990). The series of LAD's through middle to late Eocene times suggests a gradual climate deterioration and oxygen isotope data from DSDP Site 277 in the Southwest $\mathrm{Pa}$ cific imply the beginning of increased bottom water circulation in the middle to late Eocene and a temperature drop just above the Eocene/Oligocene boundary (Corliss, 1981).

Sites 738 and 744 are located south of the Antarctic Convergence in Antarctic waters, in the area influenced by the Antarctic Circumpolar Current, the major ocean current circulating around Antarctica. The time of the initiation of this current has been dated to the earliest Miocene by Barker and Burrell (1982). Based on DSDP Leg 29 data from the South Tasman Rise earliest signs of the ACC were present in middle to late Oligocene sediments of about 30 m.y. (Kennett et al., 1974). This event is followed by a long period of worldwide deep-sea erosion creating a hiatus in the upper Oligocene and lower Neogene. The present data indicate a paleoceanographic change in the early Oligocene at the Kerguelen Plateau, possibly related to the initiation of the ACC. Strong erosional bottom current activity is reflected at Site 738 by the middle Oligocene to Miocene unconformity. The almost complete record, despite several small unconformities during that time interval at Site 744, $250 \mathrm{~km}$ farther north, suggests less erosion by the current, possibly due to local topographic barriers.

Nuttallides umbonifera dominates the Oligocene to middle Miocene sequence at Site 744. The occurrence of this species is well documented in all oceans and it is found to be more resistant to carbonate corrosive bottom water (Bremer and Lohmann, 1982; Corliss, 1979a, 1979b; Miller and Katz, 1987;
Mackensen et al., in press). Since late Oligocene time N. umbonifera has coexisted with Epistominella exigua, an epibenthic species, as reported from recent faunas (Gooday, 1988). E. exigua shows large fluctuations, however, increasing up to the Quaternary, whereas $N$. umbonifera disappears in the late Miocene. This faunal change between dominant species suggest paleoceanographic changes in terms of calcium carbonate saturation (Mackensen et al., in press). The epibenthic life position of $E$. exigua also makes the species less vulnerable to carbonateaggressive pore-water chemistry, which is created by high flux of organic matter. The increasing dominance of this species is coeval with the move of the Polar Front and a high production of biosiliceous sedimentation providing an increased supply of organic matter to the sediment. Furthermore E. exigua has a preference for areas with a high food supply (Mackensen et al., 1985).

Another faunal change occurring in the middle Miocene has also been recognized in the North Atlantic (Schnitker, 1984; Miller and Katz, 1987; Thomas, 1986b, 1986c). These changes have been related to either a decrease in temperature as documented by changes in oxygen isotope values (Schnitker, 1984; Douglas and Woodruff, 1981; Woodruff, 1985) or to increased primary productivity (Miller and Katz, 1987). This faunal change occurs in the equatorial Pacific somewhat earlier in the early to middle Miocene (Thomas, 1985; Douglas and Woodruff, 1981; Woodruff, 1985) and appears to be the result of an increase in surface productivity which creates a variable corrosivity of the bottom water (Thomas and Vincent, 1987). Stable isotope data of this particular interval in preparation will shed some light on this question (Woodruff and Chambers, this volume). 


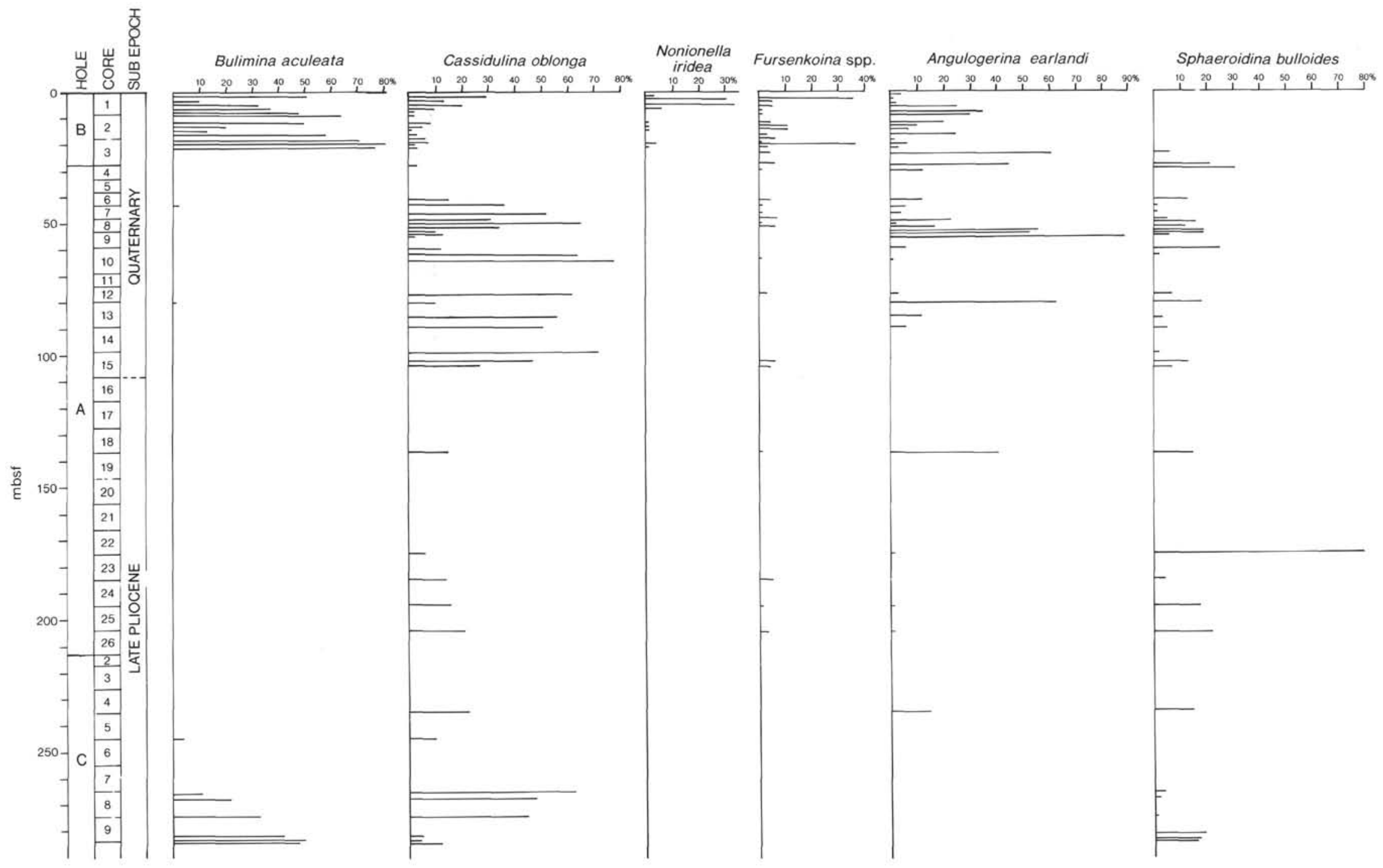

Figure 8. Relative abundance of selected species at Site 736, including all samples with a minimum of 100 specimens per $10 \mathrm{~cm}^{3}$. 
It has been argued that the modern deep-sea benthic foraminiferal fauna developed during the early Oligocene and that no major faunal turnover took place since that time (Boltovskoy, 1980; Boltovskoy and Boltovskoy, 1988). The results of Sites 738 and 744 partly support this theory. Many taxa that appear at the Eocene/Oligocene boundary have ranges through to the Holocene. These species are not affected by the described faunal change in the middle Miocene. Assemblage 2 is marked by additional short-ranging species, which occur fairly commonly for a short period of time. No comparable fauna in other parts of the deep-sea record was found. It remains questionable which paleoenvironmental conditions were favored by these species.

\section{CONCLUSIONS}

1. The upper Pliocene to Quaternary section at Site 736 on the northern Kerguelen Plateau beneath the modern-day Polar Front is marked by short pulses of high absolute abundances of benthic foraminifers interrupted by barren intervals. The absence of foraminifers is associated with high-productivity zones of biosiliceous phytoplankton. It is still questionable if these intervals can be correlated with local shifts of the Polar Front.

2. The Holocene assemblage is dominated by Bulimina aculeata. This species is connected with a high supply of organic matter, which prevents the preservation of these tests in the fossil record. More resistant species such as Angulogerina earlandi remain downcore and become the dominant taxa.

3. Together, Sites 738 and 744 provide an almost continuous record of the Eocene to Holocene age. Five benthic assemblages are defined in this time interval. The transitions between assemblages are gradational and are not marked by large extinction events.

4. The Eocene fauna is dominated by Nuttallides truempyi. During the late Eocene the genus Bulimina took over, and at the end of the Eocene many long-ranging taxa became established. These broad faunal changes of dominant constituents were recognized in other oceans.

5. The establishment of the Antarctic Circumpolar Current in the early Oligocene caused long-term erosion at Site 738 as a result of the development of strong bottom currents. At Site 744 this paleoceanographic change is connected with the beginning of a cold, more carbonate-corrosive watermass which is suggested by the increase in relative abundance of Nuttallides umbonifera in the early Oligocene. This event follows the first signs of glaciation in Antarctica during the early Oligocene, which may have precipitated the large faunal turnover at the Eocene/ Oligocene boundary.

6. The upper Miocene to Quaternary interval is dominated by Epistominella exigua. This species prefers a high nutrient supply and as an epibenthic species shows resistance against corrosive sediment, which favors preservation. The establishment of the Polar Front since late Miocene time provided these conditions and $E$. exigua increased in abundance.

\section{ACKNOWLEDGMENTS}

I thank the captain, crew, and technical staff of the JOIDES Resolution for an excellent cruise and successful sampling. All of the shipboard paleontologists provided stimulating discussions. Ellen Thomas, John Barron, David Scott, and one unknown reviewer provided constructive criticism of the manuscript. Chloe Younger prepared the samples. Denise Then provided assistance with the drafting. Franco Medioli and Eric Collins helped with the photography. I like to express sincere thanks to all of them. I also like to thank my husband Peter Adams for his critical comments of the manuscript and my daughter Katrina, who was born during the preparation of this paper, for her cooperation. Financial support was provided by the $\mathrm{Na}$ tional Science and Engineering Research Council of Canada with a Cooperative Special Programmes Grant to D. B. Scott and an Operating Grant to F. S. Medioli (Dalhousie University).

\section{REFERENCES}

Barker, P. F., and Burrell, J., 1982. The influence upon Southern Ocean circulation, sedimentation, and climate of the opening of the Drake Passage. In Craddock, C. (Ed.), Antarctic Geoscience: Madison (Univ. of Wisconsin), 377-385.

Barron, J., Larsen, B., et al., 1989. Proc. ODP, Init. Repts., 119: College Station, TX (Ocean Drilling Program).

Berggren, W. A., and Aubert, J., 1976. Eocene benthonic foraminiferal biostratigraphy and paleobathymetry of Orphan Knoll (Labrador Sea). Micropaleontology, 22:327-346.

Berggren, W. A., Kent, D. V., Flynn, J. J., and Van Couvering, J. A., 1985. Cenozoic geochronology. Geol. Soc. Am. Bull., 96:1407-1418.

Berggren, W. A., and Miller, K. G., 1989. Cenozoic bathyal and abyssal calcareous benthic foraminiferal zonations. Micropaleontology, 35: 308-320.

Boersma, A., 1984. Oligocene and other Tertiary benthic foraminifers from a depth traverse down Walvis Ridge, Deep Sea Drilling Project Leg 74, Southeast Atlantic. In Hay, W. W., Sibuet, J.-C., et al., Init. Repts. DSDP, 75: Washington (U.S. Govt. Printing Office), 12731300.

Boltovskoy, E., 1978. Late Cenozoic benthonic Foraminifera of the Ninetyeast Ridge (Indian Ocean). Mar. Geol., 26:139-178.

1980. On the benthonic bathyal-zone foraminifera as stratigraphic guide fossils. J. Foraminiferal Res., 10:163-172.

Boltovskoy, E., and Boltovskoy, D., 1988. Cenozoic deep-sea benthic foraminifera: faunal turnovers and paleobiogeographic differences. Rev. Micropaleontol., 31:67-84.

Bremer, M. L., and Lohmann, G. P., 1982. Evidence for primary control of the distribution of certain Atlantic Ocean benthonic foraminifera by degree of carbonate saturation. Deep-Sea Res. Part A, 29: 987-988.

Corliss, B. H., 1979a. Quaternary Antarctic bottom-water history: deep sea benthonic foraminiferal evidence from the southeast Indian Ocean. Quat. Res., 12:271-286.

, 1979b. Recent deep-sea benthonic foraminiferal distributions in the southeast Indian Ocean: inferred bottom-water routes and ecological implications. Mar. Geol., 31:115-138.

, 1981. Deep-sea benthonic foraminiferal faunal turnover near the Eocene/Oligocene boundary. Mar. Micropaleontol., 6:367-384.

Corliss, B. H., Aubry, M.-P., Berggren, W. A., Fenner, J. M., Keigwin, L. D., and Keller, G., 1984. The Eocene/Oligocene boundary event in the deep sea. Science, 226:806-810.

Cushman, J. A., and Parker, F. L., 1947. Bulimina and related foraminiferal genera. Geol. Surv. Prof. Pap. U.S., 210-D:55-176.

Douglas, R. G., and Woodruff, F., 1981. Deep-sea benthic foraminifera. In Emiliani, C. (Ed.), The Sea (Vol. 7): New York (Wiley-Interscience), 1233-1327.

Gooday, A. J., 1988. A response by benthic foraminifera to the deposition of phytodetritus in the deep sea. Nature, 332:70-73.

Gordon, A. L., 1971. Oceanography of Antarctic waters. In Reid, J. L. (Ed.), Antarctic Oceanology I. Am. Geophys. Union, Antarct. Res. Ser., 15:169-203.

Kemp, E. M., Frakes, L. A., and Hayes, D. A., 1975. Paleoclimatic significance of diachronous biogenic facies, Leg 28. In Hayes, D. E., Frakes, L. A., et al., Init. Repts. DSDP, 28: Washington (U.S. Govt. Printing Office), 909-917.

Kennett, J. P., Houtz, R. E., Andrews, P. B., Edwards, A. R., Gostin, V. A., Hajos, M., Hampton, M. A., Jenkins, D. G., Margolis, S. V., Ovenshine, A. T., and Perch-Nielsen, K., 1974. Development of the Circum-Antarctic Current. Science, 186:144-147.

Leckie, R. M., and Webb, P.-N., 1986. Late Paleogene and early Neogene foraminifers of Deep Sea Drilling Project Site 270, Ross Sea, Antarctica. In Kennett, J. P., Von der Borch, C. C., et al., Init. Repts. DSDP, 90: Washington (U.S. Govt. Printing Office), 10931142.

Lindenberg, H. G., and Auras, A., 1984. Distribution of arenaceous foraminifera in depth profiles of the Southern Ocean (Kerguelen Plateau Area). Palaeogeogr., Palaeoclimatol., Palaeoecol., 48:61-106.

Loeblich, A. R., and Tappan, H., 1987. Foraminiferal Genera and their Classification: New York (Van Nostrand Reinhold).

Mackensen, A., Grobe, H., Kuhn, G., and Fütterer, D. K., in press. Benthic foraminiferal assemblages from the Eastern Weddell Sea be- 
tween $68^{\circ}$ and $73^{\circ} \mathrm{S}$ : distribution, ecology and fossilization potential. Mar. Micropaleontol.

Mackensen, A., Sejrup, H. P., and Jansen, E., 1985. The distribution of living and dead benthic foraminifera on the continental slope and rise off southwest Norway. Mar. Micropaleontol., 9:275-306.

Miller, K. G., 1983. Eocene-Oligocene paleoceanography of the deep Bay of Biscay: benthic foraminiferal evidence. Mar. Micropaleontol., 7:403-440.

Miller, K. G., Curry, W. B., and Ostermann, D. R., 1985. Late Paleogene (Eocene to Oligocene) benthic foraminiferal oceanography of the Goban Spur region, Deep Sea Drilling Project Leg 80. In de Graciansky, P. C., Poag, C. W., et al., Init. Repts. DSDP, 80: Washington (U.S. Govt. Printing Office), 505-538.

Miller, K. G., and Katz, M. E., 1987. Oligocene to Miocene benthic foraminiferal and abyssal circulation changes in the North Atlantic. Micropaleontology, 33:97-149.

Parker, F. L., 1964. Foraminifera from the experimental Mohole drilling near Guadalupe Island, Mexico. J. Paleontol., 38:617-636.

Peterson, L. C., 1984. Recent abyssal benthic foraminiferal biofacies of the eastern equatorial Indian Ocean. Mar. Micropaleontol., 8:479519.

Schlich, R., Wise, S. W., et al., 1988. That sinking feeling. Nature, 334: 385-386.

Schnitker, D., 1984. High resolution records of benthic foraminifers in the late Neogene of the Northeastern Atlantic. In Roberts, D. G., Schnitker, D., et al., Init. Repts. DSDP, 81: Washington (U.S. Govt. Printing Office), 611-622.

Schröder, C. J., Scott, D. B., and Medioli, F. S., 1987. Can smaller benthic foraminifera be ignored in paleoenvironmental analyses? J. Foraminiferal. Res., 17:101-105.

Thomas, E., 1985. Late Eocene to Recent deep-sea benthic foraminifers from the central equatorial Pacific Ocean. In Mayer, L., Theyer, F., Thomas, E., et al., Init. Repts. DSDP, 85: Washington (U.S. Govt. Printing Office), 655-694.

1986a. Changes in composition of Neogene benthic foraminiferal faunas in equatorial Pacific and North Atlantic. Palaeogeogr., Palaeoclimatol., Palaeoecol., 53:47-61.

1986b. Early to middle Miocene benthic foraminiferal faunas from DSDP Sites 608 and 610, North Atlantic. In Summerhayes, C. P., and Shackleton, N. J. (Eds.), North Atlantic Palaeoceanography. Geol. Soc. Spec. Publ. London, 21:205-218.

1986c. Late Oligocene to Recent foraminifers from Deep Sea Drilling Project Sites 608 and 610, northeastern North Atlantic. In Ruddimann, W. F., Kidd, R. B., Thomas, E., et al., Init. Repts. DSDP, 94: Washington (U.S. Govt. Printing Office), 997-1031.

1990. Late Cretaceous through Neogene deep-sea benthic foraminifers (Maud Rise, Weddell Sea, Antarctica). In Barker, P. F., Kennett, J. P., et al., Proc. ODP, Sci. Results, 113: College Station, TX (Ocean Drilling Program), 571-594.

Thomas, E., and Vincent, E., 1987. Equatorial Pacific deep-sea benthic foraminifera: faunal changes before the middle Miocene polar cooling. Geology, 15:1035-1039.

Tjalsma, R. C., 1983. Eocene to Miocene benthic foraminifers from DSDP Site 516, Rio Grande Rise, South Atlantic. In Barker, P. F., Carlson, R. L., Johnson, D. A., et al., Init. Repts. DSDP, 72: Washington (U.S. Govt. Printing Office), 731-756.

Tjalsma, R. C., and Lohmann, G. P., 1983. Paleocene-Eocene bathyal and abyssal benthic foraminifera from the Atlantic Ocean. Micropaleontol. Spec, Publ: 4:1-90.

van Morkhoven, F.P.C.M., Berggren, W. A., and Edwards, A. S., 1986. Cenozoic cosmopolitan deep-water benthic foraminifera. Bull. Cent. Rech. Explor-Prod. Elf-Aquitaine, Mem. 11.

Woodruff, F., 1985. Changes in Miocene deep-sea benthic foraminiferal distribution in the Pacific Ocean: relationship to paleoceanography. In Kennett, J. P. (Ed.), The Miocene Ocean: Paleoceanography and Biogeography. Mem. Geol. Soc. Am., 163:131-175.

Date of initial receipt: 19 December 1989

Date of acceptance: 19 July 1990

Ms 119B-152

\section{APPENDIX A}

Alphabetical list of all species shown in Figure 4 (range chart

Site 738

63 Alabamina dissonata

79 Alabamina sp. A

50 Amphimorphina ignota

67 Anomalina praeacuta

64 Anomalina spissiformis

29 Astrononion umbilicatulum

34 Bigeneria nodulosa

27 Bolivina decussata

65 Bolivina huneri

35 Bolivinopsis cubensis

66 Bulimina basistriata var. nuda

55 Bulimina elongata

78 Bulimina glomarchallengeri

56 Bulimina macilenta

44 Bulimina semicostata

57 Bulimina simplex

39 Bulimina thanetensis

68 Bulimina trihedra

14 Cibicides lobatulus

1 Cibicidoides bradyi

22 Cibicidoides ef. cicatricosus

61 Cibicidoides subspiratus

2 Cibicidoides wuellerstorfi

30 Cibicidoides ungerianus

74 Clinapertina inflata

15 Cyclammina pusilla

72 Dentalina sp. A

3 Eggerella bradyi

4 Epistominella exigua

5 Epistominella vitrea

23 Eponides weddellensis

70 Fursenkoina sp. A

80 Gavelinella danica

40 Gavelinella micra

71 Gavelinella semicribrata

6 Globocassidulina subglobosa

7 Gyroidina lamarckiana

41 Gyroidina orbiculare

16 Gyroidina soldanii

73 Gyroidina zelandica

62 Gyroidinoides globosus

61 Gyroidinoides subspiratus

24 Gyroidinoides sp. A

36 Hanzawaia ammophila

28 Heronallenina sp. A

17 Karreriella bradyi

45 Karreriella cubensis

46 Karreriella subglabra

18 Laticarinina pauperata

69 Lenticulina whitei

8 Melonis pompilioides

42 Neoeponides lunata

51 Nodosaria monile

75 Nodosaria velascoensis

43 Nonion havanensis

25 Nonion sp. A

9 Nonionella iridea

26 Nuttallides umbonifera

52 Nuttallides truempyi

47 Ophthalmidium pusillum

19 Oridorsalis umbonatus

37 Orthomorphina antillea

48 Orthomorphina havanensis

49 Osangularia mexicana

58 Pleurostomella bellardi

81 Pleurostomella brevis

83 Pleurostomella naranjoensis

20 Pleurostomella obtusa 


\section{J. SCHRÖDER-ADAMS}

10 Pullenia bulloides

76 Pullenia coryelli

59 Pullenia eocenica

11 Pullenia osloensis

21 Pullenia subcarinata

12 Pyrgo spp.

77 Quadrimorphina profunda

82 Siphogenerinoides elongata

13 Stainforthia complanata

53 Stilostomella gracillima

31 Stilostomella lepidula

32 Stilostomella subspinosa

38 Turrilina alsatica

60 Turrilina robertsi

33 Uvigerina peregrina

84 Vaginulinopsis praelonga

54 Vulvulina spinosa 744).

Alphabetical list of all species shown in Figure 6 (range chart Site

70 Anomalina praeacuata

66 Anomalina spissiformis

30 Astrononion umbilicatulum

50 Bigeneria nodulosa

40 Bolivina seminuda

59 Bolivina silvestrina

25 Bolivina thalmanni

60 Bolivinopsis cubensis

57 Bulimina alazanensis

63 Bulimina simplex

62 Bulimina striata

21 Cibicides lobatulus

28 Cibicidoides bradyi

24 Cibicidoides cf. cicatricosus

67 Cibicidoides laurisae

29 Cibicidoides mundulus

54 Cibicidoides pseudoungerianus

31 Cibicidoides robertsonianus

45 Cibicidoides trinitatensis

64 Cibicidoides ungerianus

1 Cibicidoides wuellerstorfi

33 Dentalina communis

2 Eggerella bradyi

3 Epistominella exigua

34 Epistominella rotunda

4 Epistominella vitrea

48 Eponides weddellensis

58 Fursenkoina bradyi

72 Gavelinella semicribrata

5 Globocassidulina subglobosa

6 Gyroidina lamarckiana

27 Gyroidina orbiculare

26 Gyroidina soldanii

68 Gyroidina sp. A

73 Gyroidinoides globosus

51 Gyroidinoides sp. A

74 Hanzawaia ammophila

52 Heronallenina sp. A

22 Karreriella bradyi

7 Laryngosigma sp.

35 Laticarinina pauperata

39 Martinotiella nodulosa

8 Melonis barleeanus

9 Melonis pompilioides

65 Neoeponides lunata

23 Nonion sp. A

10 Nonionella iridea

77 Nuttallides truempyi

53 Nuttallides umbonifera

42 Ophthalmidium pusillum

11 Oridorsalis umbonatus

32 Orthomorphina antillea

61 Osangularia culter

75 Osangularia mexicana

36 Pleurostomella acuta
55 Pleurostomella alternans

37 Pleurostomella obtusa

12 Pullenia bulloides

13 Pullenia osloensis

14 Pullenia quinqueloba

15 Pullenia subcarinata

16 Pyrgo spp.

17 Pyrolina extensa

47 Quinqueloculina venusta

49 Sigmoilina edwardsi

18 Siphotextularia curta

43 Spiroloculina depressa

19 Stainforthia complanata

56 Stilostomella annulifera

76 Stilostomella gracillima

46 Stilostomella lepidula

4 Stilostomella subspinosa

20 Triloculina oblonga

69 Turrilina alsatica

38 Uvigerina peregrina

41 Uvigerina proboscidia

71 Vulvulina spinosa

\section{APPENDIX B}

Alphabetical list of all identified species. Numerous taxa with still unknown generic identification are not included.

Alabamina creta $($ Finlay $)=$ Pulvinulinella creta Finlay

Alabamina dissonata $($ Cushman and Renz) $=$ Pulvinulinella atlantisae Renz var. dissonata Cushman and Renz

Alabamina sp.

Ammonia sp.

Amphicoryna hirsuta (d'Orbigny) $=$ Nodosaria hirsuta d'Orbigny

Amphimorphina ignota Cushman and Siegfus

Amphimorphina sp.

Angulogerina earlandi Parr

Anomalina globosa Chapman and Parr

Anomalina praeacuta Vasilenko

Anomalina sp.

Anomalina spissiformis Cushman and Stainforth

Anomalinoides pseudogrosserugosus (Colon) = Anomalina pseudo-

grosserugosa Colon

Anomalinoides sp.

Astrononion echolsi Kennett

Astrononion pusillum Hornibrook

Astrononion umbilicatulum Uchio

Bathysiphon sp.

Bigeneria nodulosa d'Orbigny

Bolivina decussata Brady

Bolivina globulosa Cushman

Bolivina huneri Howe

Bolivina pseudopunctata Höglund

Bolivina seminuda Cushman

Bolivina silvestrina Cushman

Bolivina striatula Cushman

Bolivina thalmanni Renz

Bolivina sp.

Bolivinopsis cubensis $($ Cushman and Bermudez) $=$ Spiroplectoides cubensis Cushman and Bermudez

Brizalina spinescens $($ Cushman $)=$ Bolivina spinescens Cushman

Bulimina aculeata d'Orbigny

Bulimina alazanensis Cushman

Bulimina basistriata var. nuda Howe and Wallace

Bulimina bradbury Martin

Bulimina elongata d'Orbigny

Bulimina exilis Brady

Bulimina glomarchallengeri Tjalsma and Lohmann

Bulimina impendens Parker and Bermudez

Bulimina macilenta Cushman and Parker

Bulimina marginata d'Orbigny

Bulimina semicostata Nuttall

Bulimina simplex Terquem

Bulimina striata d'Orbigny

Bulimina thanetensis Cushman and Parker

Bulimina translucens Parker 
Bulimina trihedra Cushman

Buliminella grata Parker and Bermudez

Cassidella bradyi $($ Cushman $)=$ Virgulina bradyi Cushman

Cassidulina laevigata d'Orbigny

Cassidulina oblonga Reuss

Cibicides lobatulus (Walker and Jacob) $=$ Nautilus lobatulus Walker and Jacob

Cibicidoides aknerianus (d'Orbigny) $=$ Rotalina akneriana d'Orbigny

Cibicidoides bradyi $($ Trauth) $=$ Truncatulina bradyi Trauth

Cibicidoides cf. cicatricosus $($ Schwager) $=$ Anomalina cicatricosa

Schwager

Cibicidoides grimsdalei $($ Nuttall $)=$ Cibicides grimsdalei Nuttall

Cibicidoides haitiensis (Coryell and Rivero) $=$ Cibicides robertsonianus (Brady) var. haitiensis Coryell

Cibicidoides laurisae (Mallory) $=$ Cibicides laurisae Mallory

Cibicidoides mundulus (Brady, Parker and Jones) = Truncatulina

mundula Brady, Parker and Jones

Cibicidoides perlucidus $($ Nuttall) $=$ Cibicides perlucida Nuttall

Cibicidoides pseudoungerianus (Cushman) $=$ Truncatulina pseudoungeriana Cushman

Cibicidoides robertsonianus (Brady) $=$ Truncatulina robertsoniana

Brady

Cibicidoides subspiratus (Nuttall) $=$ Cibicides subspiratus Nuttall tall

Cibicidoides trinitatensis $($ Nuttall) $=$ Truncatulina trinitatensis Nut-

Cibicidoides tuxpamensis $($ Cole $)=$ Cibicides tuxpamensis Cole Cibicides ungerianus (d'Orbigny) $=$ Rotalina ungeriana d'Orbigny Cibicidoides wuellerstorfi $($ Schwager) $=$ Anomalina wuellerstorf $i$ Schwager

Clavulina sp.

Clinapertina inflata Tjalsma and Lohmann

Cribrostomoides subglobosus $($ Sars) $=$ Lituola subglobosa Sars

Cyclammina pusilla Brady

Cystammina argentea Earland

Dentalina communis d'Orbigny

Dentalina ittai Loeblich and Tappan

Dentalina pauperata d'Orbigny

Dentalina reussi Neugeboren

Dentalina spp.

Discorbis sp.

Eggerella bradyi (Cushman) $=$ Verneuilina bradyi Cushman

Ehrenbergina carinata Eade

Ehrenbergina sp. A

Epistominella exigua $($ Brady $)=$ Pulvinulina exigua Brady

Epistominella rotunda (Husezima and Maruhashi) $=$ Eponides ro-

tundus Husezima and Maruhashi

Epistominella rugosa $($ Phleger and Parker $)=$ Cibicides rugosa Phle-

ger and Parker

Epistominella vitrea Parker

Eponides weddellensis Earland

Eponides pusillus Parr

Eponides sp. A

Francesita advena $($ Cushman $)=$ Virgulina advena Cushman

Francescita sp. A

Frondicularia sp.

Fursenkoina bradyi (Cushman) $=$ Virgulina bradyi Cushman

Fursenkoina ciperana (Cushman and Stainforth) $=$ Virgulina $c i$ perana Cushman and Stainforth

Fursenkoina cylindrica $($ Cushman and Bermudez $)=$ Virgulina cylindrica Cushman and Bermudez

Fursenkoina earlandi $($ Cushman $)=$ Virgulina earlandi Cushman

Fursenkoina fusiformis (Williamson) = Bulimina pupoides var. $f u$ -

siformis Williamson

Fursenkoina sp. A

Gaudryina laevigata Franke

Gavelinella capitata $($ Gümpel) = Rotalina capitata Gümpel

Gavelinella danica (Brotzen) = Cibicides danica Brotzen

Gavelinella micra (Bermudez) $=$ Cibicides micrus Bermudez

Gavelinella semicribrata (Beckmann) $=$ Anomalina pompilioides

Galloway and Heminway var. semicribrata Beckmann

Glandulina antarctica Parr

Glandulina sp.

Globobulimina pacifica Galloway and Wissler
Globocassidulina subglobosa (Brady) = Cassidulina subglobosa Brady Gyroidina lamarckiana (d'Orbigny) = Rotalina lamarckiana d'Orbigny

Gyroidina soldani d'Orbigny

Gyroidina zelandica Finlay

Gyroidinoides globosus $($ Hagenow) $=$ Nonionina globosa Hagenow Gyroidinoides spp.

Hanzawaia ammophila (Gümpel) = Rotalia ammophila Gümpel

Heronallenina sp. A

Heronallenina sp. B

Hormosina pilulifer Brady

Hyperammina sp.

Karreriella bradyi (Cushman) = Gaudryina bradyi Cushman

Karreriella chapapotensis $($ Cole $)=$ Textularia chapapotensis Cole

Karreriella cubensis Cushman and Bermudez

Karreriella subglabra (Gümpel) = Gaudryina subglabra Gümpel

Karreriella sp.

Kyphopyxa sp.

Lagena spp.

Laryngosigma spp.

Laticarinina pauperata (Parker and Jones) $=$ Pulvinulina repanda Fichtel and Moll var. menardii d'Orbigny subvar. pauperata Parker and Jones

Lenticulina cultrata d'Orbigny

Lenticulina whitei Tjalsma and Lohmann

Lenticulina spp.

Marginulina obesa Cushman

Marginulina sp.

Martinotiella nodulosa $($ Cushman $)=$ Clavulina nodulosa Cushman

Melonis affine (Reuss) = Nonionina affinis Reuss

Melonis barleeanus $($ Williamson $)=$ Nonionina barleeana Williamson

Melonis pompolioides $($ Fichtel and Moll $)=$ Nautilus pompilioides Fichtel and Moll

Miliammina arenacea $($ Chapman $)=$ Miliolina oblonga (Montagu)

var. arenacea Chapman

Neoeponides lunata $($ Brotzen $)=\mathrm{cf}$. Eponides lunata Brotzen

Nodosaria limbata d'Orbigny

Nodosaria monile Hagenow

Nodosaria sulcata Nilsen

Nodosaria velascoensis Cushman

Nodosaria vertebralis (Batsch) $=$ Nautilus vertebralis Batsch

Nonion grateloupi (d'Orbigny) = Nonionina grateloupi d'Orbigny

Nonion havanensis Cushman and Bermudez

Nonion sp. A

Nonion sp. B

Ninionella iridea Heron-Allen and Earland

Nonionellina sp.

Nuttallides truempyi $($ Nuttall $)=$ Eponides truempyi Nuttall

Nuttallides umbonifera (Cushman) $=$ Pulvinulinella umbonifera Cushman

Oolina spp.

Ophthalmidium pusillum $($ Earland $)=$ Spiroloculina pusilla Earland

Oridorsalis umbonatus (Reuss) = Rotalina umbonata Reuss

Oridorsalis spp.

Orthomorphina antillea $($ Cushman $)=$ Nodosaria antillea Cushman Orthomorphina challengeriana $($ Thalmann $)=$ Nodogenerina challengeriana Thalmann

Orthomorphina glandigena $($ Schwager) $=$ Nodosaria glandigena Schwager

Orthomorphina havanensis $($ Cushman and Bermudez $)=$ Nodogenerina havanensis Cushman and Bermudez

Orthomorphina himerensis (de Amicis) $=$ Nodosaria himerensis de Amicis

Orthomorphina perversa $($ Schwager $)=$ Nodosaria perversa Schwager

Osangularia culter (Parker and Jones) = Planorbulina culter Parker and Jones

Osangularia mexicana $($ Cole $)=$ Pulvinulinella culter Parker and Jones var. mexicana Cole

Parafissurina spp.

Pleurostomella acuminata Cushman

Pleurostomella acuta Hantken

Pleurostomella alternans Schwager 


\section{J. SCHRÖDER-ADAMS}

Pleurostomella bellardi Hantken

Pleurostomella bolivinoides Schubert

Pleurostomella brevis Schwager

Pleurostomella naranjoensis Cushman and Bermudez

Pleurostomella obtusa Berthelin

Pleurostomella tenuis Hantken

Psammosphaera fusca Schulze

Pullenia bulloides (d'Orbigny) $=$ Nonionina bulloides d'Orbigny

Pullenia coryelli White

Pullenia eocenica Cushman and Siegfus

Pullenia osloensis Feyling-Hanssen

Pullenia quinqueloba (Reuss) = Nonionina quinqueloba Reuss

Pullenia salisbury Stewart and Stewart

Pullenia subcarinata (d'Orbigny) = Nonionina subcarinata d'Orbigny

Pyrgo depressa (d'Orbigny) = Biloculina depressa d'Orbigny

Pyrgo murrhina (Schwager) = Biloculina murrhina Schwager

Pyrgo nasuta Cushman

Pyrgo spp.

Pyrolina extensa $($ Cushman $)=$ Polymorphina extensa Cushman

Pyrolina sp.

Quadrimorphina profunda Schnitker and Tjalsma

Quinqueloculina pygmaea Reuss

Quinqueloculina seminula (Linné) = Serpula seminulum Linné

Quinqueloculina venusta Karrer

Quinqueloculina sp.

Recurvoides contortus Earland

Reophax pilulifer Brady

Reticulophragmium orbicularis $(\mathrm{Brady})=$ Cyclammina orbicularis Brady

Robulus rotulatus $($ Lamarck) $=$ Lenticulina rotulata Lamarck

Sigmoilina edwardsi (Schlumberger)

Siphogenerinoides cf. brevispinosa Cushman

Siphonodosaria sp.

Siphotextularia curta (Cushman) $=$ Textularia flintii var. curta Cushman

Sphaeroidina bulloides d'Orbigny
Spiroloculina antillarum d'Orbigny

Spiroloculina asperula Karrer

Spiroloculina depressa d'Orbigny

Spiroplectammina spectabilis $($ Grzybowski) $=$ Spiroplecta spectalilis

Grzybowski

Stainforthia complanata (Egger) = Virgulina schreibersiana Czjzek

var. complanata Egger

Stilostomella annulifera (Cushman and Bermudez) $=$ Ellipsonodosaria annulifera Cushman and Bermudez

Stilostomella gracillima (Cushman and Jarvis) = Ellipsonodosaria nuttalli var. gracillima Cushman and Jarvis

Stilostomella lepidula $($ Schwager $)=$ Nodosaria lepidula Schwager

Stilostomella subspinosa $($ Cushman $)=$ Ellipsonodosaria subspinosa

Cushman

Textularia wiesneri Earland

Trifarina angulosa (Williamson) = Uvigerina angulosa Williamson Trifarina bradyi Cushman

Triloculina oblonga $($ Montagu $)=$ Vermiculum oblongum Montagu

Trochammina sp.

Turrilina alsatica Andreae

Ellis

Turrilina robertsi $($ Howe and Ellis) $=$ Bulimina robertsi Howe and

Uvigerina graciliformis Papp

Uvigerina havanensis Cushman and Bermudez

Uvigerina peregrina Cushman (group)

Uvigerina rippensis Cole

Uvigerina schencki Asano

Uvigerina semicostata Cushman

Uvigerina senticosa Cushman

Uvigerina spinicostata Cushman and Jarvis

Vaginulina subelegans Parr

Vaginulinopsis praelonga ten Dam

Vaginulinopsis tasmanica Parr

Valvulineria laevigata Phleger and Parker

Vulvulina jarvisi Cushman

Vulvulina spinosa Cushman 

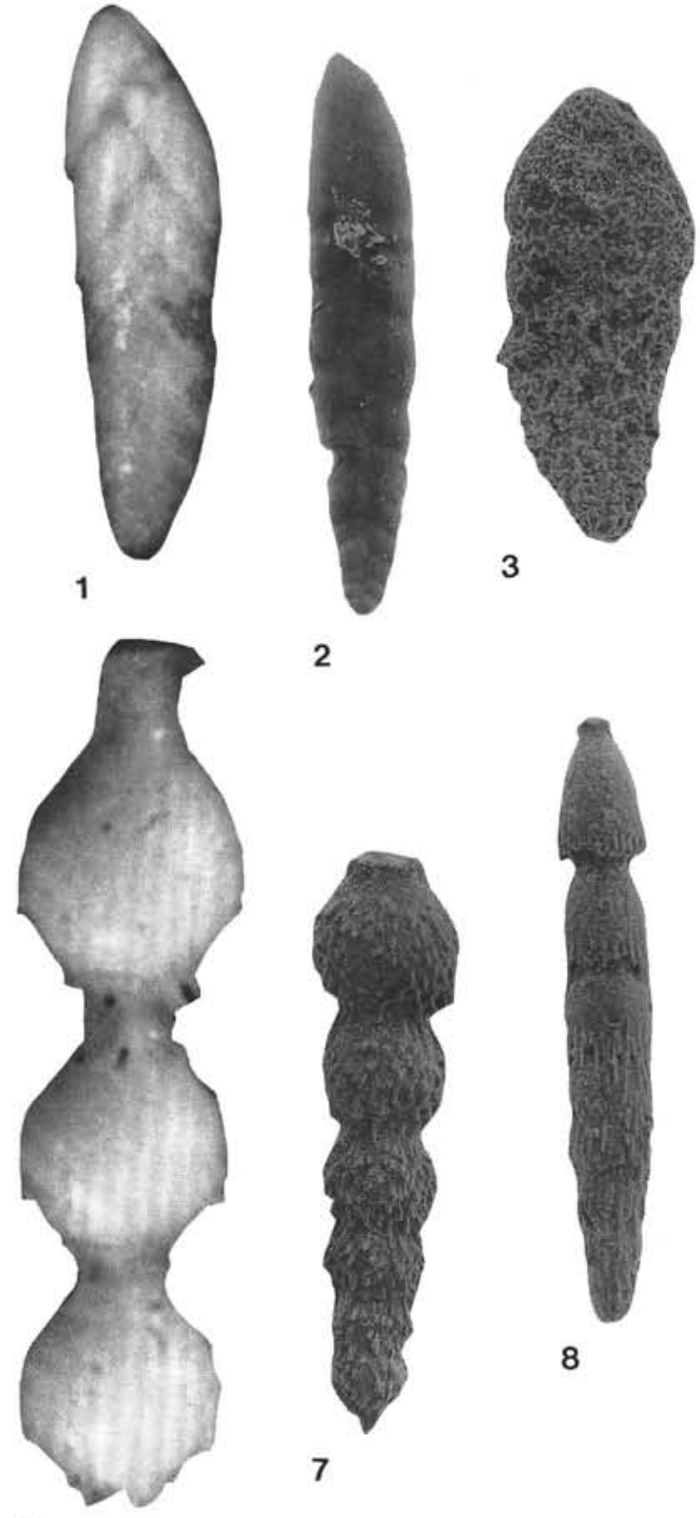

6

2

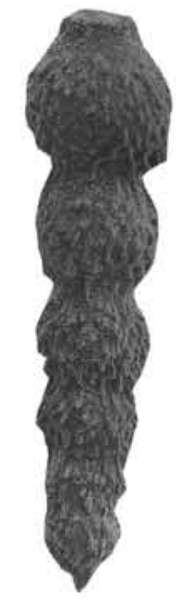

7

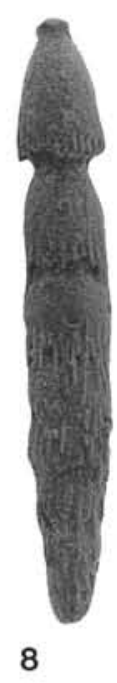

8

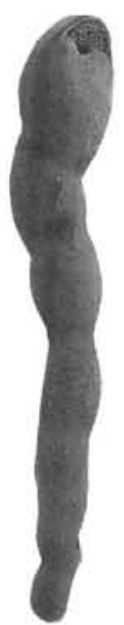

9
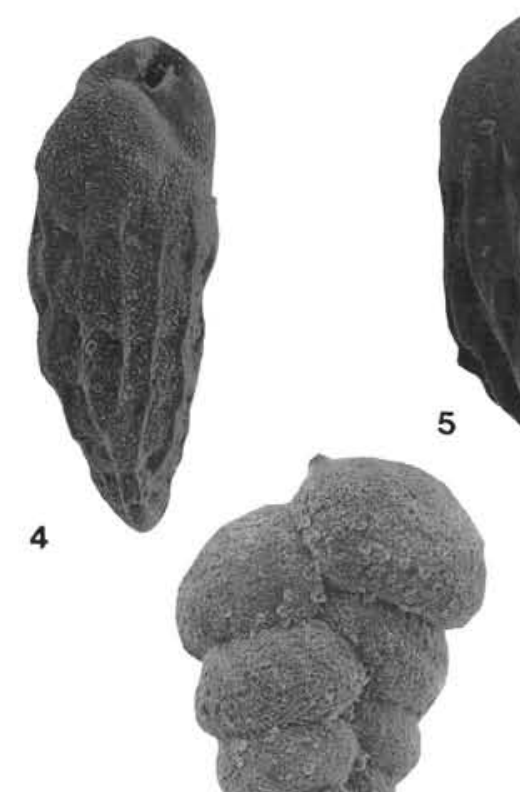

5

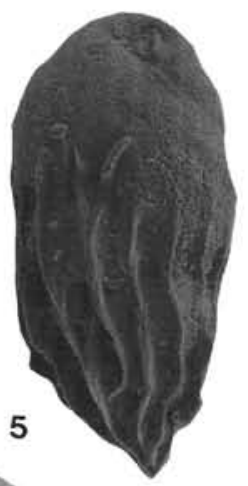

10
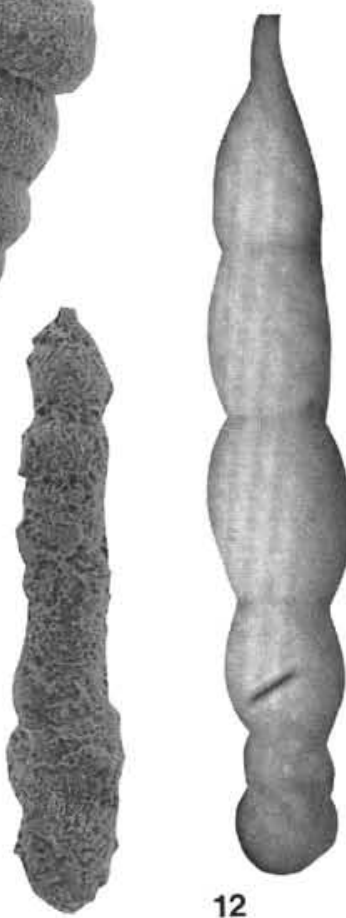

12

Plate 1. 1, 2. Bolivina pseudopunctata Höglund, Sample 119-736B-2H-4, 115-120 cm, $\times 451$. 3. Bolivina thalmanni Renz, Sample $119-744 \mathrm{~B}-6 \mathrm{H}-$ $1,125-130 \mathrm{~cm}, \times 516$. 4. Bulimina semicostata Nuttall, Sample 119-738B-23X-CC, $\times 810$. 5. Bulimina alazanensis Cushman, Sample $119-744 \mathrm{~B}-$ $9 \mathrm{H}-4,125-130 \mathrm{~cm}, \times 561$. 6. Stilostomella lepidula (Schwager), Sample 119-738B-13H-CC, $\times 305 . \quad 7$. Stilostomella subspinosa (Cushman), Sample 119-738B-13H-CC, $\times 241$. 8. Orthomorphina antillea (Cushman), Sample 119-738B-11H-CC, $\times 437$. 9. Pleurostomella obtusa Berthelin, Sample 119-744A-14H-CC, $\times 271$. 10. Karreriella cubensis Cushman and Bermudez, Sample 119-738B-7H-CC, $\times 585$. 11. Bigeneria nodulosa d'Orbigny, Sample 119-744A-18H-CC, $\times 274$. 12. Orthomorphina havanensis (Cushman and Bermudez), Sample 119-738B-11H-CC, $\times 310$. 


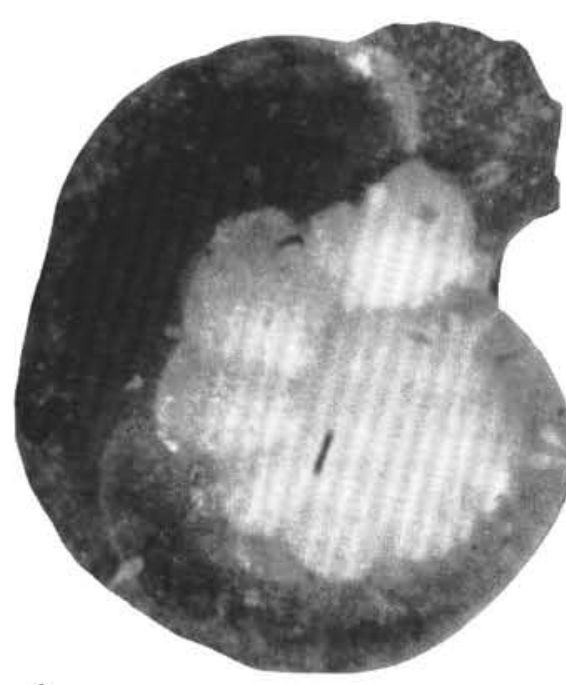

1

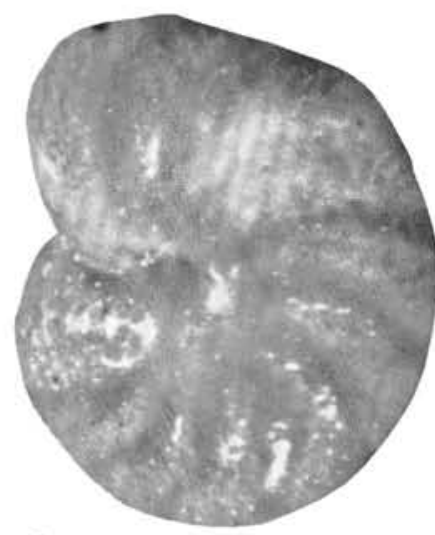

6

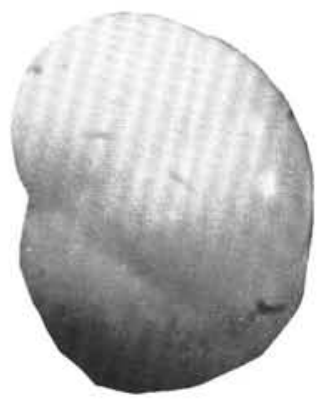

10

11

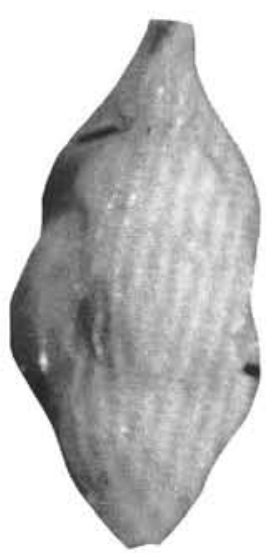

2

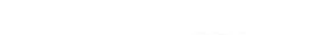

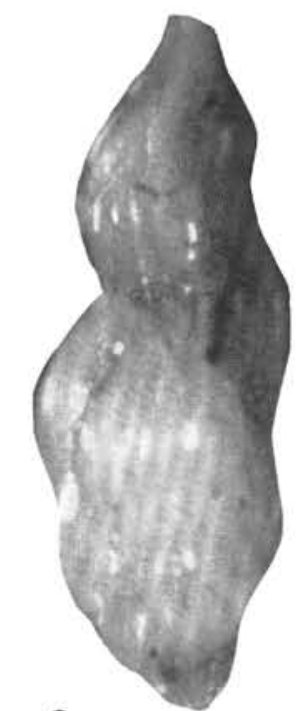
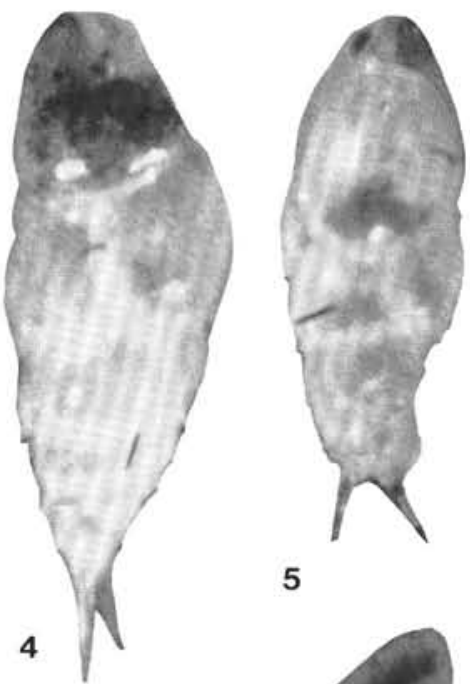

5 3
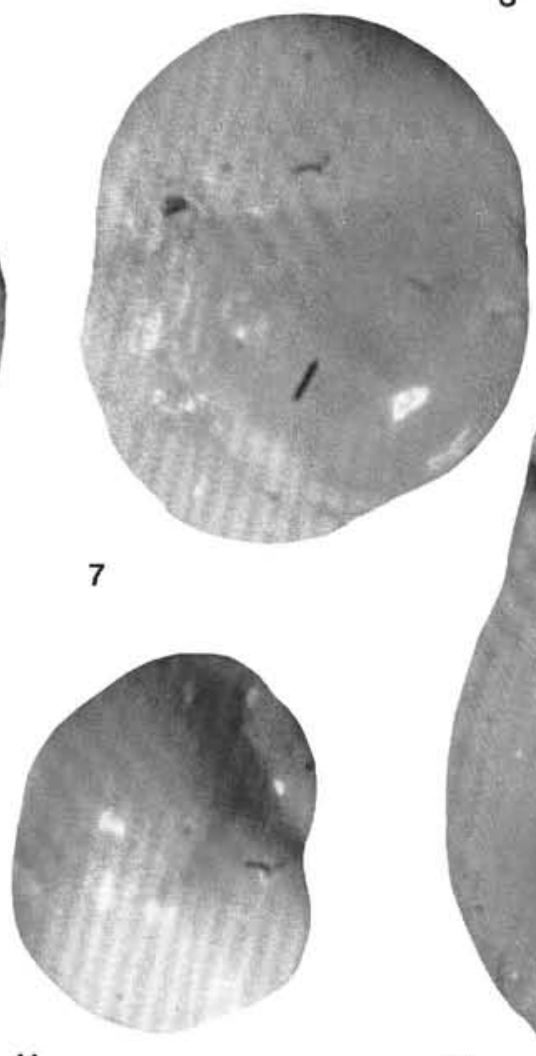

12

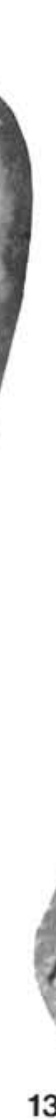

Plate 2. 1. Laticarinina pauperata (Parker and Jones), Sample 119-744B-7H-1, 120-125 cm, $\times 66$. 2, 3. Angulogerina earlandi Parr, Sample 119. 736B-2H-2, 115-120 cm, $\times 85$. 4, 5. Bulimina aculeata d'Orbigny, Sample 119-736B-1H-1, 115-120 cm, $\times 175$. 6. Melonis barleeanus (Williamson), Sample 119-736B-2H-2, 115-120 cm, $\times 106$. 7. Sphaeroidina bulloides d'Orbigny, Sample 119-736C-10R-2, 115-120 cm, $\times 100$. 8. Ophthalmidium pusillum (Earland), Sample 119-744B-6H-3, 125-130 cm, $\times 197$. 9. Stainforthia complanata (Egger), Sample 119-736A-4H-1, 115-120 $\mathrm{cm}, \times 210$. 10, 11. Cassidulina oblonga Reuss, Sample 119-736A-8H-CC, $\times 120$. 12. Spiroloculina depressa d'Orbigny, Sample 119-744B-6H-3, $125-130 \mathrm{~cm}, \times 88$. 13. Bolivinopsis cubensis (Cushman and Bermudez), Sample 119-738B-12 H-CC, $\times 156$. 


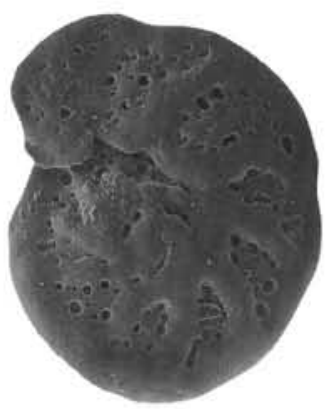

1

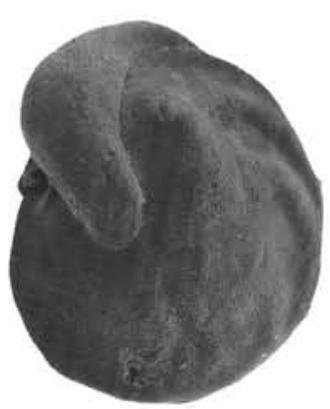

2

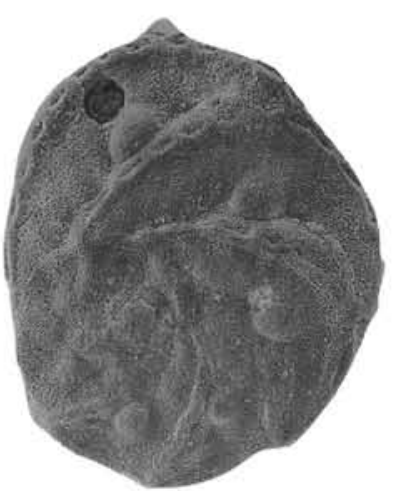

3

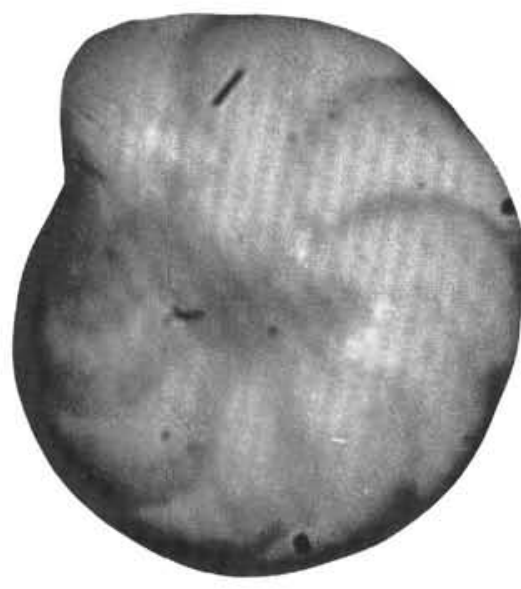

6

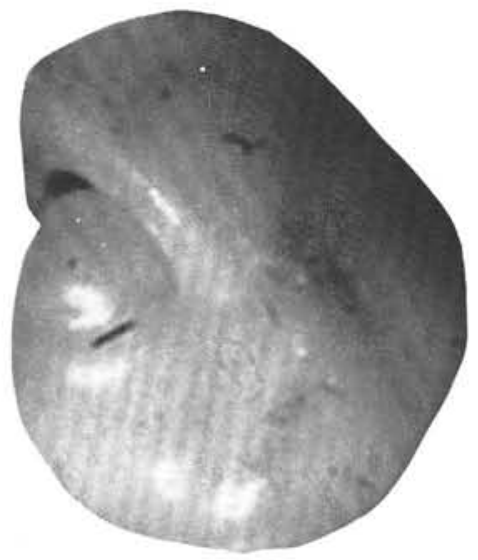

8

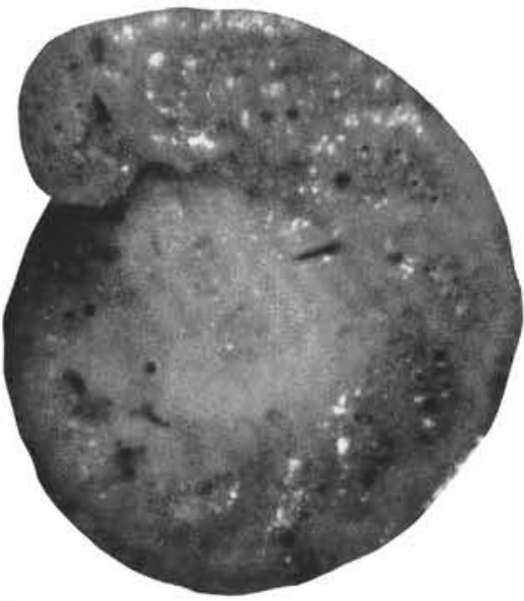

5

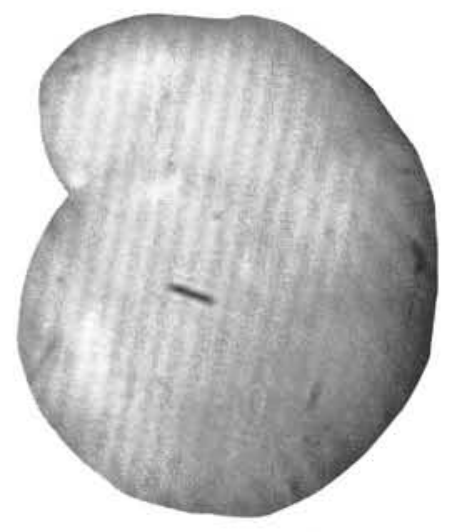

9

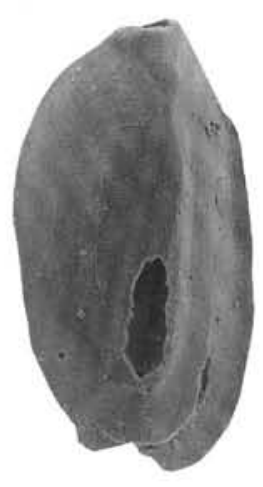

10

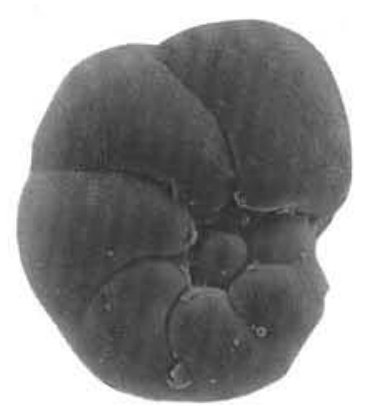

4

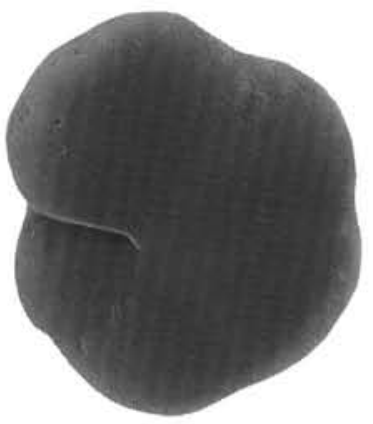

7

Plate 3. 1, 2. Cibicidoides wuellerstorfi (Schwager), 1, spiral side, 2, umbilical side, Sample 119-744B-1H-3, 25-27 cm, $\times 195$. 3. Heronallenia sp. A, Sample 119-744B-7H-5, 120-125 cm, $\times 460$. 4. Nonionella iridea Heron-Allen and Earland, Sample 119-736B-1H-2, 115-120 cm, $\times 460$. 5, 6. Cibicidoides ungerianus (d'Orbigny), 5, spiral side, 6, umbilical side, Sample 119-744A-19H-CC, $\times 380$. 7. Pullenia osloensis Feyling-Hanssen, Sample 119-744B-1H-2, 25-27 cm, $\times 491$. 8. Pullenia subcarinata (d'Orbigny), Sample 119-744B-6H-2, 125-130 cm, $\times 395$. 9. Gyroidina lamarckiana (d'Orbigny), Sample 119-744B-7H-3, 120-125 cm, $\times 166$. 10. Quinqueloculina venusta Karrer, Sample 119-744B-6H-4, 125-130 cm, $\times 304$. 11. Ehrenbergina sp. A, Sample $119-744 \mathrm{~B}-7 \mathrm{H}-1,120-125 \mathrm{~cm}, \times 302$. 


\section{J. SCHRÖDER-ADAMS}

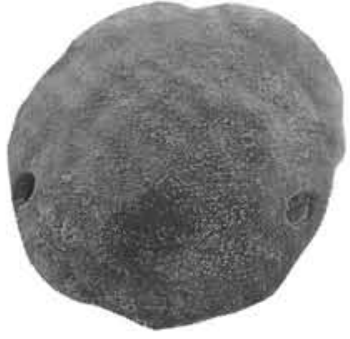

1

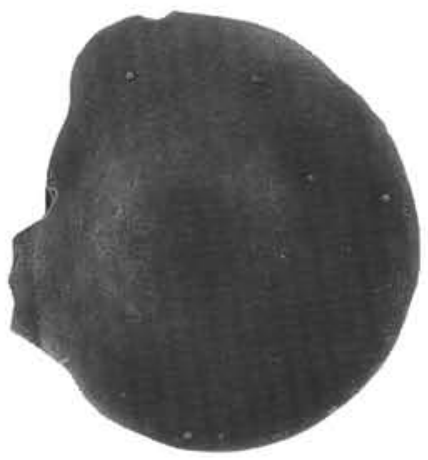

5

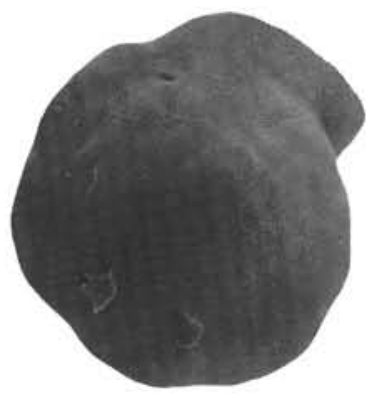

9

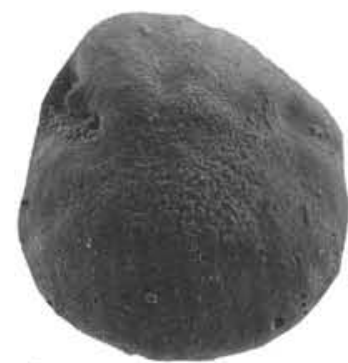

2

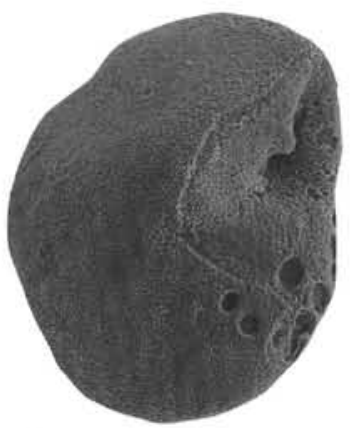

6

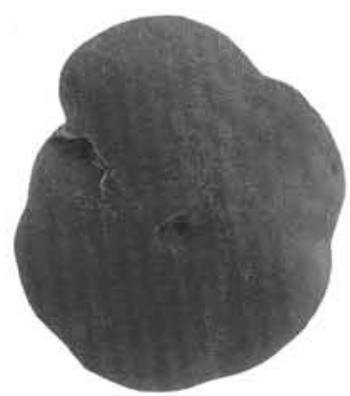

10

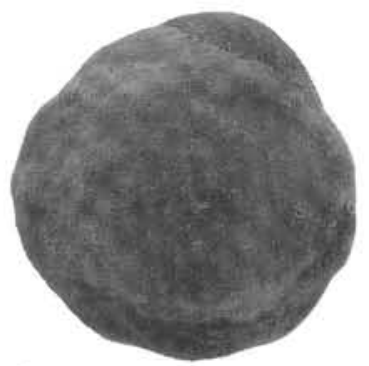

3

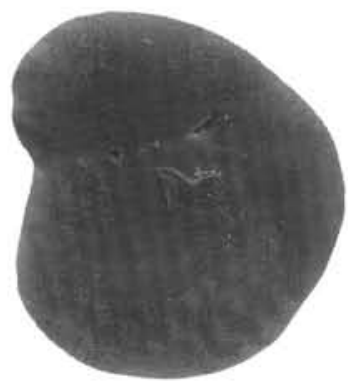

7

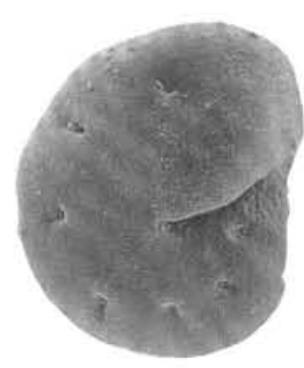

11

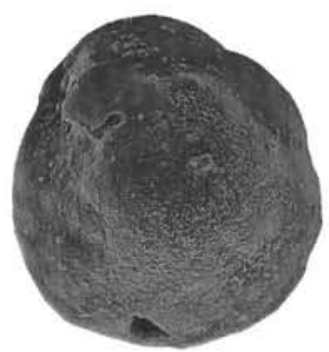

4

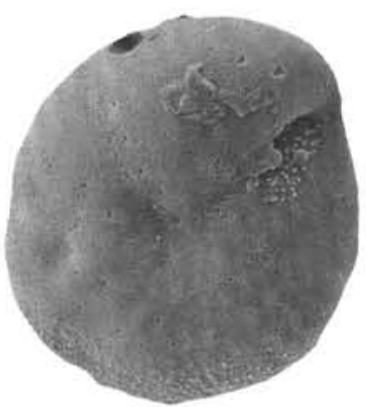

8

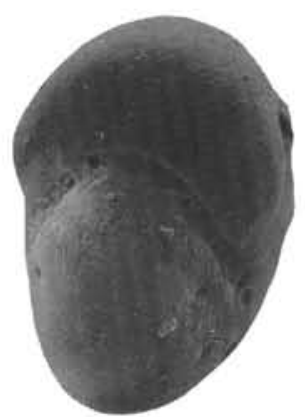

12

Plate 4. 1, 2. Nuttallides umbonifera (Cushman), 1, spiral side, 2, umbilical side, Sample 119-744B-7H-1, 120-125 cm, $\times 354 . \quad 3,4$. Nuttallides truempyi (Nuttall), 3, spiral side, 4, umbilical side, Sample 119-738B-9H-CC, $\times 354 . \quad 5,6$. Epistominella exigua (Brady), 5, spiral side, 6, umbilical side, Sample 119-744B-4H-2, 25-27 cm, $\times 459$. 7, 8. Epistominella vitrea Parker, 7, spiral side, 8, umbilical side, Sample 119-744B-1H-1, 2-4 cm, $\times 459$. 9, 10. Oridorsalis umbonatus (Reuss), 9, spiral side, 10, umbilical side, Sample 119-744A-12H-CC, $\times 453$. 11, 12. Astrononion umbilicatulum Uchio, 11, side view, 12, aperture view, Sample 119-744B-7H-1, 120-125 cm, $\times 397$. 